
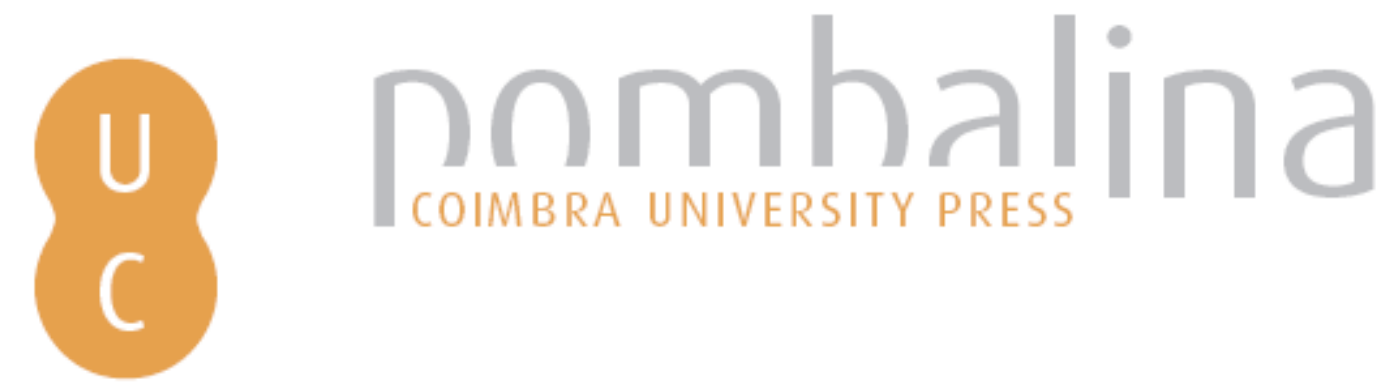

O soneto como preâmbulo confidencial na poesia camoniana
Autor(es):
Dasilva, Xosé Manuel
Publicado por: Imprensa da Universidade de Coimbra
URL
persistente:
URI:http://hdl.handle.net/10316.2/30779
DOI:
DOI:http://dx.doi.org/10.14195/978-989-26-0569-2_15
Accessed : $\quad$ 26-Apr-2023 06:21:53

A navegação consulta e descarregamento dos títulos inseridos nas Bibliotecas Digitais UC Digitalis, UC Pombalina e UC Impactum, pressupõem a aceitação plena e sem reservas dos Termos e Condições de Uso destas Bibliotecas Digitais, disponíveis em https://digitalis.uc.pt/pt-pt/termos.

Conforme exposto nos referidos Termos e Condições de Uso, o descarregamento de títulos de acesso restrito requer uma licença válida de autorização devendo o utilizador aceder ao(s) documento(s) a partir de um endereço de IP da instituição detentora da supramencionada licença.

Ao utilizador é apenas permitido o descarregamento para uso pessoal, pelo que o emprego do(s) título(s) descarregado(s) para outro fim, designadamente comercial, carece de autorização do respetivo autor ou editor da obra.

Na medida em que todas as obras da UC Digitalis se encontram protegidas pelo Código do Direito de Autor e Direitos Conexos e demais legislação aplicável, toda a cópia, parcial ou total, deste documento, nos casos em que é legalmente admitida, deverá conter ou fazer-se acompanhar por este aviso.

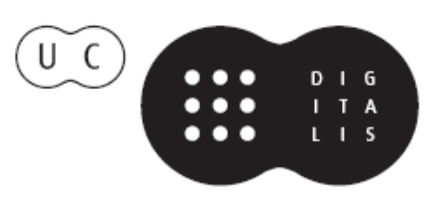




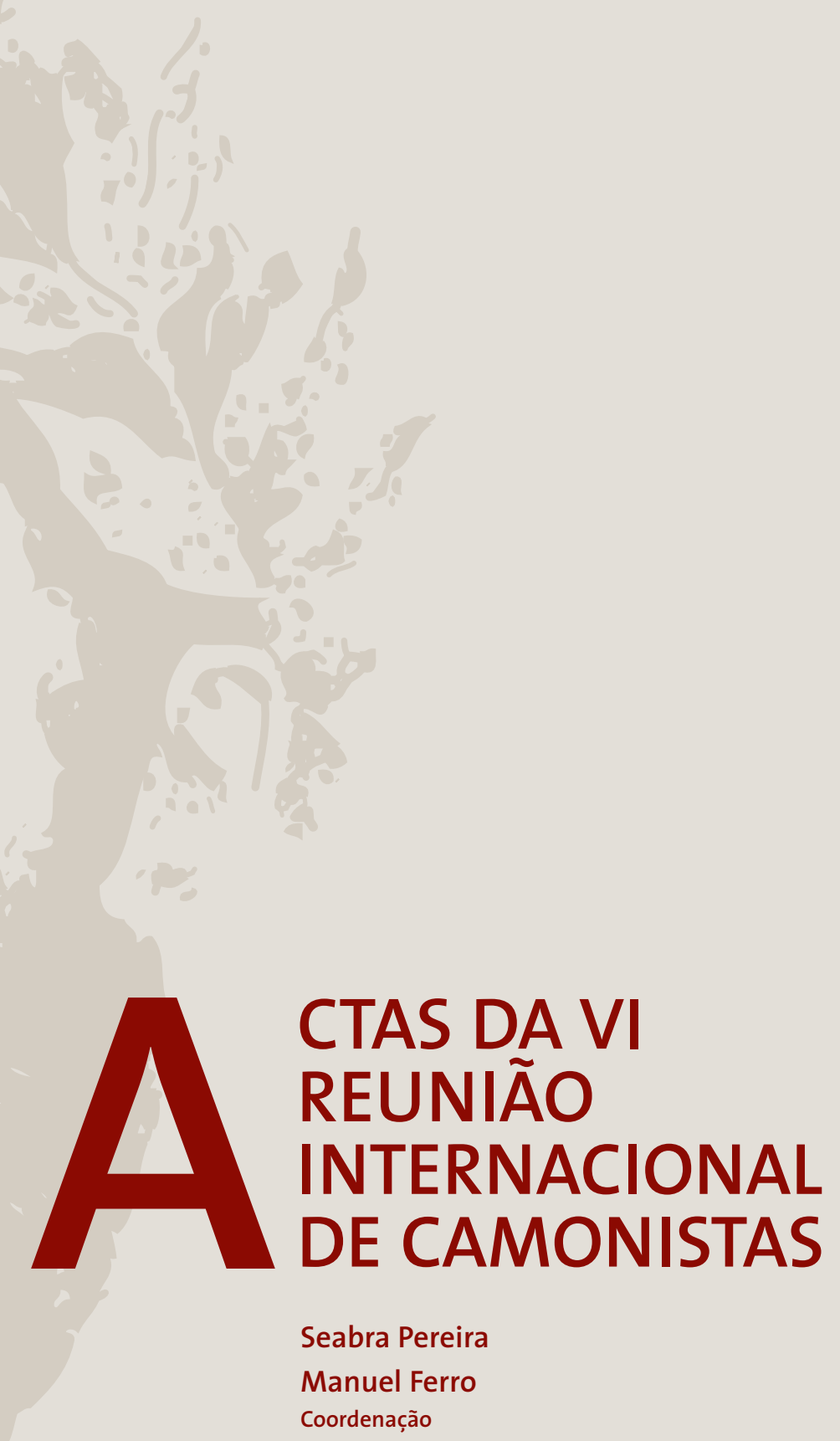


Xosé Manuel Dasilva

Universidade de Vigo

\section{O SONETO COMO PREÂMBULO CONFIDENCIAL NA POESIA CAMONIANA}

Numa reveladora conferência proferida em 1980 no decurso dos actos de celebração do IV Centenário de Camóes na Fundación Juan March, intitulada "Aspectos petrarquistas da lírica de Camóes”, o Prof. Aguiar e Silva defendia a tese táo sugestiva de se necessitar compreender o propósito original da poesia petrarquiana, e portanto da criaçáo lírica de todos os poetas pertencentes a essa estética, de construir uma vida desde a palavra poética segundo os princípios modelares do tópico ideológico imitatio vitae $^{1}$. Esta ideia basilar supôs com certeza um fértil sinal de alerta para trazer à memória dos investigadores camonianos uma via hermenêutica muito fecunda que é o ponto de partida crítico inevitável, aliás, que funciona com enorme produtividade respeito a todo o lirismo europeu com origem na obra vulgar de Petrarca. Um elemento de grande valor na teorização do Prof. Aguiar e Silva, talvez o de maior transcendência, inclusivamente nesta perspectiva hermenêutica, era a advertência de a relação amorosa estabelecida entre o escritor de Arezzo e a sua amada Laura não ser mais do que um dado de ordem ficcional, até ao ponto de merecer apenas uma estimação relativa a discutível existência empírica da destinatária do amor do poeta, assim como a sinceridade psicológica, no âmbito amoroso quando não mais, do amante que a louva com apaixonado desígnio através dos versos do seu canto lírico.

Parece verdadeiramente adequado não esquecer que se este prodigioso fingimento é inerente à história amorosa que se refere no Canzoniere petrarquiano, todos os poetas com raiz lírica nessa fonte, com escassas excepçôes salientáveis, imitaram o princípio criador surpreendente, para aquela altura, de conceber a escrita do discurso poético como a transfiguração literária do próprio percurso biográfico em matéria amorosa, dando origem a uma mágica liga em que se fundem existência e literatura, verdade e invenção. E é preciso que náo se produza tal esquecimento porque não raro a imitatio vitae como aspecto central da poesia petrarquista, a organizar de um plano superior

1 Vítor Manuel de Aguiar e Silva, "Aspectos petrarquistas da lírica de Camões», em VV. AA., Cuatro lecciones sobre Camoens, Madrid, Fundación Juan March - Cátedra, 1981, pp. 99-116. Trabalho reproduzido na sua recente colecção de artigos camonianos Camóes: Labirintos e Fascinios, Lisboa, Cotovia, 1994, pp. 179-190. 
outros aspectos meramente estilísticos ou temáticos ${ }^{2}$, tem sido utilizada por meio de um ângulo leitor desviado, para se tirarem de numerosos textos interpretaçóes biografistas que prescindiram do conhecimento da corrente literária tópica em que se inserem as criaçóes poéticas derivadas do modelo ficcional inaugurado por Petrarca ${ }^{3}$.

É palpável o olhar biografista com que de modo insistente ao longo da história foi realizada a análise crítica da poesia camoniana, sem diferençar o que pertence realmente ao âmbito da realidade e o que é próprio do âmbito da criação literária, misturando-se portanto elementos existenciais e elementos estéticos. O motivo principal da utilização dessa focagem errónea há que atribuí-lo à ausência de suficientes dados certos para reconstituir o percurso vital de Camóes, o que originou uma via de estudo muito perigosa, empregada reiterativamente por uma boa parte dos biógrafos camonianos, que consistiu em construir conjecturas apenas alicerçadas na leitura subjectiva de trechos da sua obra. Mesmo isso seria um pormenor pouco importante se tal estratégia tivesse ficado na área restrita das pesquisas biográficas, mas estorvou embaraçosamente a interpretaçáo literária dos poemas ao partir-se do falso preceito de julgar que as aventuras amorosas que se poetizam segundo o código literário petrarquista são verídicas. As consequências mais graves de tal comportamento crítico, uma vez trasladado esse pensamento pouco criterioso ao campo dos estudos literários, traduziram-se na consolidação de dois círculos viciosos: por um lado, a opinião de os textos conterem dados biográficos que podem servir, por sua vez, para interpretar melhor esses mesmos textos; por outra parte, a ideia de as hipóteses biografistas serem úteis para determinar a autoria segura de peças discutíveis que, depois de se considerarem camonianas, valem para fixar a autenticidade ou a falsidade de poemas ainda mais duvidosos.

No entanto, a experiência literária que define a lírica amorosa clássica europeia mostra-se como um repositório sistemático de textos com evidentes recorrências que respondem a uma colecção náo muito ampla de motivos temáticos e de procedimentos expressivos, de tal modo que na sua cristalização apresenta grande importância a participação do contexto criador em que eles se originam ${ }^{4}$. Parece evidente que são as teorias estéticas italianas formuladas no período renascentista que funcionam com total supremacia como modelo que chegou a configurar, por seu turno, a ideologia estética

${ }^{2}$ Vid. Luigi Baldacci, Il petrarchismo italiano nel Cinquecento, 2a ed., Milano - Napoli, Riccardo Ricciardi Editore, 1957, pp. 103-104.

${ }^{3}$ Diz Umberto Bosco sobre a confusão entre vida e criação literária que se transparenta nos mesmos versos petrarquianos: "Il Petrarca, abbiam detto, non solo teorizza, ma attua la sua vita poetica. Ora, in lui è sempre estremamente difficile distinguere quel che fa e dice per impulso autonomo del suo sentire, da quello che invece fa e dice per suggestione diretta o indiretta dei suoi libri, cioè dei suoi classici» (Umberto Bosco, Francesco Petrarca, Bari, Editori Laterza, 1961, pp. 111-112).

${ }^{4}$ É curioso observar como o conceito de imitatio da poesia petrarquista está já presente na própria poesia de Petrarca respeito aos clássicos: "Ma è chiaro che, in questa stessa solenne ed eloquente dichiarazione, il concetto di originalità è per lui strettamente connesso con quello del necessario riattaccarsi alla tradizione letteraria: originalità è imitazione: sol che questa non dev'essere furto, ma emulazione. Siamo alle radici italiane della poetica che avrà nel maturo Rinascimento la sua particolareggiata formulazione, e dominerà sino al Romanticismo» (Bosco, Francesco..., p. 129). 
das restantes literaturas ocidentais 5 . A influência da tradição torna-se, portanto, de valor essencial na criação particular de cada texto dessa altura, já que se pode supor sem custo que o artista de essência petrarquista, ao realizar os seus poemas, levava inevitavelmente em conta os modelos literários imediatos mais prestigiados, entre eles a destacar naturalmente Petrarca. Faz-se necessário considerar que o escritor lírico petrarquista não submete por via de regra a feição dos seus poemas à pressão dos mecanismos sociais, que ficam em grande medida à margem do processo de criação, nem inclui como argumentos temáticos passos da sua própria experiência biográfica mais íntima, pelo menos de forma literal, mas concede interesse sobretudo aos factos da tradição literária, quer para imitá-los com muita aproximação, quer para transformálos com originalidade ${ }^{6}$.

É indispensável ter em conta que existe uma diferença extraordinária entre a arte clássica e a arte moderna, cifrada no restrito conceito de sistematização tópica e formal que caracteriza aquela em oposição à concepção livre e aberta da literatura que surge após o Romantismo. Decerto nos séculos XVI e XVII há uma férrea e inflexível organização tópica tanto no plano temático quanto no plano expressivo que exige

\footnotetext{
${ }_{5}$ "Quede de manifiesto el principio, universalmente aceptado, de la absoluta supremacía de la Teoría Estética italiana en el periodo renacentista. Siguiéndose, naturalmente, la condición de base modélica de la misma que configuró contemporánea y sucesivamente la ideología general estética en los demás países: Inglaterra, Francia y España. La proclamación anterior no es para nosotros una simple confesión de principio, obligada pero carente de novedad, sino que pretendemos alcance a justificar una eficaz identificación de la estética italiana con el programa general estético europeo imperante durante el periodo renacentista» (Antonio García Berrio, "La teoría literaria en la edad renacentista", Studia Philologica Salamanticencia, 5 (1980), p. 101). Para uma excelente e completa análise da preceptiva literária italiana, nítida origem em muitos casos das preceptivas pertencentes a outras literaturas romances, vid. especialmente B. Weinberg, A History of Literary Criticism in the Italian Renaissance, 2a ed., Chicago, University of Chicago Press, 1974, 2 vols; id., Tratatti di Poetica e Retorica del 500, Roma - Bari, Gius. Laterza \& Figli, 1970-1974, 4 vols.

6 Cfr. Antonio García Berrio, «Tradición tópica y complejidad textual», Acta Semiótica, 3, 1 (1979), p. 90. Há diversos trabalhos de Antonio García Berrio para compreender cabalmente este aspecto fundamental da criação poética petrarquista. Vid., por exemplo, "A Text-typology of the Classical Sonnets», Poetics, 8 (1979), pp. 435-458; «Construcción textual en los sonetos de Lope de Vega. Tipología del macrocomponente sintáctico», Revista de Filología Española, 6 (1979), pp. 23-147; «Definición macroestructural de la lírica amorosa de Quevedo (Un estudio de forma interior en los sonetos)", em Homenaje a Quevedo. Actas de la II Academia Literaria Renacentista, Salamanca, Universidad de Salamanca, 1982, pp. 261-293; «Estatuto del personaje en el soneto amoroso del Siglo de Oro", em VV. AA., Le personnage dans la littérature du siècle d'or: statut et fonction, Paris, Éditions Recherche sur les Civilisations, 1984, pp. 1-20; «Estructura y función del personaje en la lírica amorosa del Siglo de Oro», Lexis, IV, I (1980), pp. 71-77; «Lingüística del texto y texto lírico. La tradición textual como contexto", Revista Española de Lingüistica, 8, I (1978), pp. 19-75; «Macrocomponente textual y sistematismo tipológico: el soneto amoroso español de los siglos XVI y XVII y las reglas del género", Zeitschrift für Romanische Philologie, 97, 1-2 (1981), pp. 146-171; "Nuevas perspectivas para el estudio de la lírica en los Siglos de Oro», em Francisco Rico, ed., Historia Crítica de la Literatura Española, vol. III, Barcelona, Editorial Crítica, 1983, pp. 736-741; «Poética e ideología del discurso clásico», Revista de Literatura, XLI, 81 (1979), pp. 5-40; «Problemas de la determinación del tópico textual. El soneto en el Siglo de Oro", Anales de Literatura Española. Universidad de Alicante, I (1983), pp. 135-205; "Text Linguistics and the Lyric Text", em E. Forastieri-Braschi et al., eds., On Text and Context. Methodological Approaches to Context of Literature, Puerto Rico, Universidad de Río Piedras, 1980, pp. 95-138; «Tipología textual de los sonetos espańoles sobre el carpe-diem», Dispositio, III, 9 (1978), pp. 243-293; "Una tipologia testuale di sonetti amorosi nella tradizione classica spagnola», Lingua e Stile, III (1980), pp. 451-478.
} 
compreender, de uma perspectiva hodierna, a presença em cada texto de um catálogo de normas limitado e concreto que é o que explica, em suma, o seu carácter artístico. Deve-se prestar especial atençáo, por conseguinte, às diferentes conexôes que cabe destrinçar entre cada texto singular e o conjunto de preceitos da tradição literária em que ele se insere, de importância decisiva na sua elaboração por parte do criador ${ }^{7}$. Com essa estratégia metodológica poder-se-á ultrapassar com mais rigor a simples discriminação da natureza tópica ou inédita do texto, um objectivo que em muitos casos, aliás, o investigador moderno busca conseguir com o uso de aproximaçóes actuais que baseiam erroneamente a qualidade estética do texto no seu grau de originalidade, concentrando-se melhor na análise do facto indiscutível de que o criador clássico tem como especial meta artística, digna de todo o mérito, a retractio, isto é, a disposição sob novos ângulos estéticos dos temas e das formas que herda legitimamente dos seus antecessores ${ }^{8}$.

Apesar de que possa suscitar alguma classe de resistência compreendê-lo nestes termos, a verdade é que cumpre aceitar que o ideal estético da poética antiga se compóe de um sistema definido e condicionado de preceitos bastante escassos em que a liberdade criadora do poeta fica constrangida de uma maneira apreciável ${ }^{9}$. É por isso que parece equívoco e impróprio procurar exclusivamente na análise crítica de um autor petrarquista da época o seu suposto nível de originalidade, quando acontece que esse mesmo autor se achava fortemente determinado por uma regra, fundamental na ideologia estética predominante, que consistia em fazer da repetição e da reprodução dos modelos um indubitável valor e não, como hoje se poderia pensar falaciosamente, um sintoma de pobre capacidade literária para inventar novos universos líricos. Até se pode afirmar que a poesia de origem essencialmente petrarquiana, irradiada a todo o espaço europeu ocidental ${ }^{10}$, é, sem lugar a muitas dúvidas, mais do que mesmo uma escola literária bastante estereotipada, uma estética sectária - no melhor sentido do vocábulo, por antecipado - organizada a partir de um catálogo de assuntos e formas com uso continuado perante os quais o poeta selecciona aqueles que são da sua preferência com a colaboração imprescindível da própria memória cultural ${ }^{11}$.

7 Vid. García Berrio, «Macrocomponente textual...», p. 146.

8 Antonio García Berrio, Teoría de la literatura (La construcción del significado poético), Madrid, Cátedra, 1989, pp. 96-97.

9 «En conjunto, pues, el ideal estético del discurso antiguo, al servicio de un marcado y explícito destino prefijado, se constituía como un juego limitadísimo de libertades e iniciativas del escritor. En su dimensión pragmática el arte clásico funcionaba dentro de un código sin sorpresas ideológicas. La libertad, como veremos, radicaba más bien en la dimensión estrictamente literaria, formal. Conscientes del poder social de la literatura, los poderes clásicos embridaron férreamente la libertad ideológica del artista, a través de un mosaico perfectamente delimitado de piezas semánticas fijadas de antemano, donde toda libertad fuera sintáctica. constructiva, combinatoria; y aun ésta, siempre que no enmascarara minimamente el conservadurismo ideológico, sin sobresaltos, del discurso» (García Berrio, «Poética e ideología...», p. 29).

10 É clara a admiração profunda por Petrarca em Portugal mostrada por numerosos poetas mesmo com dissímeis aptidōes artísticas: «(...) il guardare al Petrarca è, come per gli altri paesi suppergiù nella stessa epoca, l'aspirare alla perfezione, da parte di poeti minori e maggiori» (Giuseppe Carlo Rossi, "La poesia del Petrarca in Portogallo", Cultura Neolatina, XXII (1943), p. 175).

11 Vid. Víctor Infantes, «En busca del lector perdido: la recepción de la poesía culta (1543-1600)», Edad de Oro, XII (Otoño 1993), p. 142. 
Necessita-se aceitar, todavia, que o estudo das fontes literárias a respeito da poesia camoniana não tem sido uma prática crítica habitual como produto de diversas motivaçôes de natureza apenas impressionista ou de índole mais objectiva ${ }^{12}$. Na primeira linha é preciso aludir o temor experimentado em ocasióes perante a descoberta de evidentes influências alheias nos versos de Camôes que obedeceriam à imitatio como princípio fulcral da poética classicista, porquanto isso poderia significar alguma classe de desmerecimento para o poeta e a redução da sua glória literária ${ }^{13}$. Na segunda linha, a qual tem sido defendida mais razoavelmente, diga-se a verdade, há que fazer referência aos problemas levantados por aquelas aproximações tão-só baseadas em fontes, por vezes como consequência de vagas sugestóes, que pretenderam provar a letigimidade de certas leituras interpretativas elaboradas com singeleza de uma perspectiva restritamente genética e não ajustadamente contextualizada. Tratar-se-ia de uma focagem positivista de orientação oitocentista, preocupada primordialmente com o cômputo de coincidências literais ${ }^{14}$ através da simples indicação de hipotéticas influências sem aprofundar no sentido mais recto do texto analisado ${ }^{15}$.

${ }^{12}$ Naturalmente a perscrutação de influências neste tipo de criação poética não deve remeter exclusivamente à obra petrarquiana, como assinalou Jorge de Sena, mas é justo que atenda à obra de outros autores, mesmo menos decisivos, pertencentes à mesma escola lírica: «Esta questão, porém, das fontes petrarquistas (e as outras italianas, de petrarquizantes, só são sempre referidas, pela crítica camoniana, as que Faria e Sousa, na sua inesgotável erudição, havia mencionado, às vezes mais num delírio de aproximaçóes, que em crítica genética válida) está precisando de reforma... Porque os petrarquistas, em toda a Europa, duraram geraçôes e foram multidão, e é feio acusar Petrarca de tudo..." (Jorge de Sena, "O Camôes da Aguilar», em Trinta Anos de Camóes. 1948-1978 (Estudos camonianos e correlatos), vol. II, Lisboa, Ediçóes 70, 1980, p. 182).

${ }^{13}$ Até foi justificada a ausência de abundantes estudos de fontes no que atinge à lírica camoniana, com efeito, pelo desejo entusiástico de se salientar a sua originalidade: "A investigação camoniana em Portugal (...) inclina-se antes a considerar uma bagatela a herança petrarquista do grande poeta nacional, para assim melhor poder destacar a sua originalidade. Esta atitude, que parte sem dúvida dum menosprezo romântico pela estética da imitação da Renascença, levou infelizmente a que só haja demonstraçôes positivistas da prática imitativa de Camóes, (...)" (Klaus Dirscherl, "Camões e a tradição do elogio feminino petrarquista», Cadernos de literatura, 11 (1982), p. 41, n. 13).

${ }^{14}$ Embora aplicada ao estudo de Os Lusíadas, é pertinente reparar na seguinte reflexấo sobre o facto de Faria e Sousa ter realizado avant la lettre, no século XVII já, uma boa parte desse trabalho de erudição: «O problema da tradição clássica em Camóes tem sido tratado de variadas maneiras, na sua maior parte em estilo de investigação de fontes (Quelleforschung). Muito antes da existência da palavra, já Faria e Sousa fez exaustivamente o estudo, para cada passo, e quase para cada verso, dos autores antigos e modernos que Camóes podia ter lido em cada caso particular, as fontes onde podia ter colbido uma sugestão, uma pista, um indício» (Américo da Costa Ramalho, «A tradição clássica em Os Lusíadas», em Estudos camonianos, Coimbra, Instituto de Alta Cultura, 1969, p. 1).

${ }^{15}$ É um grave problema de alcance geral, próprio do campo da teoria literária do comparativismo, que não atinge portanto unicamente a lírica camoniana: «Se, frequentemente, o estudo das fontes e das influências é mal visto, isso deve-se ao facto de fontes e influências serem muitas vezes apresentadas como meras hipóteses de trabalho e de leitura, o que nos parece correcto. É o seu carácter hipotético que repudia ao investigador. Perante uma parecença, uma semelhança, um ar de família entre dois textos, o investigador é tentado a estabelecer uma ligação entre duas séries de textos, uma relação directa de causa e efeito. E é neste plano que a crítica feita a tais conclusóes deve ser criticada: a fonte, a influência não são explicaçóes, são quando muito sintomas. A explicação que o investigador deve procurar, sem a qual se arrisca a cair na erudição gratuita ou no impressionismo, encontra-se no próprio texto e numa situação cultural e histórica susceptivel de caucionar, de autenticar uma ligação possivel entre um texto influente e um texto influenciado, entre uma fonte e a consequente influência» (Âlvaro Manuel Machado; Daniel-Henri Pageaux, Da Literatura Comparada à Teoria da Literatura, Lisboa, Ediçōes 70, 1988, p. 96). 
Porém, ser poeta de filiação petrarquista, e Camôes constitui um exemplo excelso desta maneira de conceber o cultivo da literatura durante a época quinhentista ${ }^{16}$, não significava na altura apenas imitar isoladamente assuntos ou formas, mas também compreender com sentido pleno, e isto é o importante, a transcendência exacta do significado que apresentava o Canzoniere de Petrarca, por uma parte, como história amorosa nascida da contemplação ligeiramente afastada, e recuperada por meio da memória, de um passado de entregas à paixão desde um presente de arrependimento correspondente ao tempo da escrita, e, por outra parte, como uma sucessão de intenso carácter narrativo constituída por factos e dados com frequência de tratamento lírico indispensável por parte dos imitadores deste modelo poético. É o conceito de canzoniere que tem causado precisamente um oceano de páginas impressionistas sobre muitos autores de estilo petrarquista, escritas a interrogar-se em volta da veracidade ou a falsidade da sua paixão sentimental, não se lembrando assim que se está diante de um amor de natureza literária, em consequência ilusoriamente vivido tão-só no território da criação poética, que supóe a base mais importante desta tradição literária.

Com efeito, é acostumado que um canzoniere petrarquista ofereça a aparência de uma autobiografia amorosa com importantes ingredientes vitais, em maior ou menor grau fruto da imaginação, que se vêem exagerados pelo alento confidencial que dá força à exposição do poeta. Essa sensação de confidencialidade que se acha mesmo implícita em qualquer canzoniere é o ponto de arranque que tem propiciado leituras em chave biografista, mas a esquecer-se, na maioria de tais leituras, que o tom lírico intensamente pessoal adoptado pelo poeta tem a sua proveniência no acento com que se exprime o texto e não na identificação consciente da figura empírica do autor com a realidade fictícia do emissor lírico ${ }^{17}$. Não tem de surpreender que até alguns exegetas

\footnotetext{
${ }^{16}$ Sem chegar a ser abundante a bibliografia sobre as influências petrarquianas na poesia de Camóes, é possível citar alguns estudos já clássicos em que se tentou anotar as dívidas camonianas respeito ao poeta de Arezzo. Vid. Arturo Farinelli, "Camōes e i poeti d'Italia», em Relazioni storiche fra l'Italia e il Portogallo. Memorie e documenti, Roma, Reale Accademia d'Italia, 1940, pp. 199-218; Antonio Padula, Camoens Petrarchista, Napoli, Società Luigi Camóes, 1904; Alberto Pimentel, "Petrarcha e Camões», em Ninho de Guincho, Lisboa, Parceria Antonio Maria Perreira, 1903, pp. 27-34; Feliciano Ramos, "A influência de Petrarca na lírica de Camóes», em Ensaios de crítica literária, série 1a, Coimbra, 1933, pp. 25-53; Giuseppe Carlo Rossi, "Ancora sul petrarchismo nella peninsola iberica», em Giuseppe Bellini, ed., Aspetti e Problemi delle Letterature Iberiche (Studi offerti a Franco Meregalli), Roma, Bulzoni Editore, 1981, pp. 319-329 e «La poesia del Petrarca in Portogallo", Cultura Neolatina, XXII (1943), pp. 175-190. Há que resenhar, aliás, os valiosos trabalhos realizados por José V. de Pina Martins em torno das ligações entre Petrarca e Camóes. Vid. "Camóes e il Rinascimento italiano", em Camóes e il Rinascimento Italiano, Roma, Accademia Nazionali del Lincei - Fundação Calouste Gulbenkian - Instituto de Alta Cultura, 1975, pp. XVII-XXIV; «Camôes lírico e o Renascimento italiano", em Actas da IV Reuniāo Internacional de Camonistas, Ponta Delgada, Universidade dos Açores, 1984, pp. 329-348; "L’humanisme dans l'oeuvre de Camões", em Camóes à la Renaissance, Bruxelles - Paris, Presses Universitaires de Bruxelles - Presses Universitaires de France, 1982, pp. 21-55; "O humanismo na obra de Camóes», Arquivos do Centro Cultural Português, XVI (1981), pp. XVII-XXIX; «Petrarca, esse primeiro moderno», Arquivos do Centro Cultural Português, VIII (1974), pp. 45-80.

17 "(...) la estructura de un canzoniere comprende la agrupación de sonetos y de otros poemas cortos entrelazados con las canciones que extienden la narrativa amorosa cuya temática se explaya en un discurso paradójico de lamento y felicidad. La narrativa culmina en una resolución de arrepentimiento con la cual el poeta impone un cierre de conversión a su autobiografia literária» (Anne J. Cruz, Imitación y transformación: el petrarquismo en la poesía de Boscán y Garcilaso de la Vega, Amsterdam - Philadelphia, John Benjamins Publishing Company, 1988, p. 66).
} 
quinhentistas da obra petrarquiana tivessem lido as Rime do poeta de Arezzo como um autêntico romance amoroso de origem autobiográfica, como um experimentado trajecto existencial, uma tendência de que poderia ser paradigma ilustrativo Alessandro Vellutello nos comentários, sob o título Il Petrarcha con l'espositione d'Alessandro Vellutello, que apôs às suas poesias líricas na edição da obra de Petrarca que publicou em $1525^{18}$. No entanto, cumpre interpretar um canzoniere petrarquista, e a esta afirmação talvez poucas ressalvas possam ser assinaladas ou até nenhuma, como a reelaboração muito brilhante de uma colecção restrita de normas poéticas e não como as fases diversas de um processo amoroso plausível. Além do exemplo transcendente que é a obra petrarquiana, qualquer colecçáo lírica com dimensão petrarquista de um poeta dessa altura é simuladamente uma espécie de diário ou memória individual de experiências amorosas organizado em tensão como uma confissão narrativa sequenciada com as partes próprias de um relato convencional, desde o preâmbulo até ao desenlace, sem deixar à margem o desenvolvimento linear que ficaria de permeio.

Ora bem, é exequível no caso editorial tão peculiar da poesia lírica camoniana desvendar a existência original de uma intençáo compositiva devedora do Canzoniere de Petrarca? Como é sobejamente conhecido, a deplorável situação autoral e textual da poesia lírica de Camóes não permite dispor confiavelmente de uma edição preparada pelo próprio escritor, a qual pudesse servir de fonte original, perfeitamente revista e corrigida, para outras reproduçóes posteriores que dela se realizarem. Também não existe um só documento autógrafo que recolha as suas composiçóes, porquanto já a primeira vez que vêm a lume os versos camonianos, no ano 1595, o responsável das Rhythmas, de publicação fatalmente póstuma ainda no mesmo século XVI, se teve de socorrer de diversas colectâneas manuscritas e nem sempre com um nível de pureza suficiente no que atinge tanto à verdadeira autoria dos poemas quanto ao estabelecimento irrepreensível das suas liçóes ${ }^{19}$.

${ }^{18}$ Sobre a perspectiva biografista utilizada por Alessandro Vellutello para outorgar virtualidade corpórea a Laura, preenchendo de dados reais todas as composiçóes do Canzoniere, vid. Antonio Prieto, "Introducción», em Petrarca, Cancionero, Barcelona, Planeta, 1985, pp. XX-XXI. Em todo o caso, é preciso não esquecer que por via de regra quase todo o petrarquismo europeu se nutriu em muitos casos não através da leitura directa de Petrarca, mas a partir do ambiente poético da Itália do século XVI, em que era um exercício comum a exegese e a imitação dos textos petrarquianos. Em torno de tal ideia, vid. Rogelio Reyes Cano, "Garcilaso desde la intertextualidad», Insula, 552 (Diciembre 1992), p. 3.

${ }^{19}$ Em qualquer caso, não se devem exagerar as dificuldades editoriais da poesia lírica camoniana desde que em nenhum momento supóem uma excepção assinalável no contexto da poesia europeia culta dos séculos XVI e XVII. Com respeito especialmente à poesia portuguesa, Aguiar e Silva tem chamado a atenção sobre o carácter póstumo de ediçóes pertencentes a Sá de Miranda, Fernão Álvares do Oriente, Pêro de Andrade Caminha, André Falcão de Resende, Fernão Rodrigues Lobo Soropita ou Frei Agostinho da Cruz, para além dos casos específicos da obra de Camóes e de António Ferreira. Visto isso, situar-se-iam fora do usual os exemplos daqueles poetas que contaram com a sua obra editada em vida graças ao seu próprio zelo textual, tais como Diogo Bernardes, Vasco Mousinho de Quevedo, Frei Bernardo de Brito, Baltasar Estaço ou D. Manuel de Portugal. Vid. Vítor Manuel de Aguiar e Silva, Maneirismo e barroco na poesia lírica portuguesa, Coimbra, Centro de Estudos Românicos, 1971, pp. 49-52. Sem ter de ir muito longe, é possível trazer à baila o dado de os dois poetas espanhóis talvez mais importantes dessa época, Garcilaso de la Vega e Luis de Góngora, não publicarem jamais a integridade da sua própria poesia. Vid. Elías L. Rivers, «La poesía culta y sus lectores", Edad de Oro, XII (Outono 1993), p. 267. No concernente à poesia espanhola, José Manuel Blecua também estabeleceu um extenso catálogo de poetas da literatura espanhola igualmente póstumos que 
Cumpre trazer à memória a notícia da fabulosa lenda, um pouco afastada da certeza ou ao menos da verosimilhança, que o historiógrafo Diogo do Couto exprimiu na sua Década VIII, escrita em 1616 e publicada em 1673. Um fragmento desta crónica histórica, nascido para passar com êxito desmedido à posteridade, explica como o autor inesperadamente se encontrou em Moçambique com Camóes ocupando-se, além de na correcção de Os Lusíadas com o objectivo de dar a obra à imprensa, em escrever «muito em um livro que ia fazendo, a que intitulava Parnaso de Luis de Camóes, livro de muita erudição, doutrina e filosofia, o qual lhe furtaram, e nunca pude saber no Reino dele, por muito que o inquiri, e foi furto notável, ${ }^{20}$. Depois, em muitas oportunidades aduzida com jeitos romanescos, acaso como consolaçáo perante o que se náo descobria, surgiu daqui a hipótese prodigiosa do roubo da lírica camoniana que confirmaria a crença esperançosa de Camóes ter preparado também um suposto Parnaso para o prelo ${ }^{21}$. Porém, deixa de haver nesta altura qualquer outra notícia ou certificação, apta para receber confiança, que confirme a verdade tanto do roubo como, sequer, da existência de tal Parnaso, um facto que vem obstruir penosamente um dos caminhos que se apresentavam mais sugestivos

inclui Gutierre de Cetina, Francisco de Figueroa, Francisco de Aldana, Fray Luis de León, San Juan de la Cruz ou Villamediana, nomes ilustres todos que levam a acreditar que as ediçóes póstumas não foram um costume menor nem, por certo, insubstancial. Vid. José Manuel Blecua, «Sobre el rigor poético en Espańa», em Sobre el rigor poético en España y otros ensayos, Barcelona, Ariel, 1977, pp. 12-13.

${ }^{20}$ Diogo do Couto, Epitome das décadas 8 e 9 da Ásia, apud IV Centenário de Os Lusíadas de Camóes (1572-1972). Catálogo de la Exposición Bibliográfica e Iconográfica, preparado y redactado por António Coimbra Martins, Madrid, Biblioteca Nacional - Fundación Calouste Gulbenkian, 1972, p. 6. É sabido que deste texto há duas versôes: uma impressa, a que pertence o trecho que se acaba de reproduzir, e outra mais extensa e de autenticidade muito incerta, já que, como demonstrou Costa Pimpão entre mais argumentações possíveis, a sua letra corresponde a fins do século XVII ou começos do XVIII. Esta última versão ficou inédita num manuscrito conservado na Biblioteca Municipal do Porto até que foi revelada em 1917. Vid. Álvaro Júlio da Costa Pimpão, ed., Luís de Camóes, Rimas, 3a ed., Coimbra, Atlântida Editora, 1973, pp. LXIV-LXVI. Nesta última versão da Década VIII figura entre outras interpolaçóes a menção, para além do Parnaso, de um surpreendente «livro de seus sonetos», do qual se recolhem os quatro primeiros versos da peça «Alma minha gentil, que te partiste» a propósito de um comentário apócrifo sobre a realidade de Dinamene como musa de Camóes. Cfr. a respeito desta questão Charles R. Boxer, "Camóes e Diogo do Couto, irmãos em armas e nas letras», Ocidente, LXXXIII (1972), pp. 25-37; António Coimbra Martins, "Camôes et Couto", em Les Cultures Ibériques en Devenir (Essais publiés en hommage à la memoire de Marcel Bataillon (1895-1977), Paris, Fondation Singer Polignac, 1979, pp. 691-705. Apesar de Coimbra Martins desvelar um novo manuscrito custodiado na Biblioteca Nacional de Madrid que é igual ao da Biblioteca Municipal do Porto, hodiernamente quase todos os investigadores acreditam que são falsas as duas versōes inéditas do famoso fragmento, já referido, da Década VIII. Só cumpriria assinalar a excepção principal de Roger Bismut, que considera que são fidedignas as informaçôes que esse manuscrito fornece. Assim, vid. Coimbra Martins, IV Centenário..., pp. 4-5; Roger Bismut, «Playdoyer pour Dinamene», Bulletin des Études Portugaises, 30 (1969), pp. 91-93; La lyrique de Camóes, Paris, Fondation Calouste Gulbenkian - Publications du Centre Culturel Portugais - Presses Universitaires de France, 1970, pp. 522-524; «Recensão Crítica. Luís de Camóes, Rimas, texto estabelecido e prefaciado por Álvaro Júlio da Costa Pimpão, 3 o ed., Coimbra, Atlântida, 1973", Arquivos do Centro Cultural Português, VIII (1974), pp. 666-670.

${ }^{21}$ Filgueira Valverde interpretou o conceito de Parnaso como próprio da poesia culta em oposição ao de Cancioneiro, que pertenceria à poesia de raiz popular: "A poesia humanística lê-se; a poesia tradicional canta-se. Também aqui as denominaçóes revelam a diversidade de propósitos: as redondilhas tradicionais aparecem reunidas em Cancioneiros, nome especialmente aplicado às composiçóes destinadas ao canto; os poetas italianizantes agrupam-se em Parnasos, nome que evoca uma aspiração humanística, antológica, superadora" (José Filgueira Valverde, Camóes, Coimbra, Livraria Almedina, 1981, p. 81). 
a fim de chegar à leitura directa de autógrafos do espólio poético de Camões ${ }^{22}$. Por conseguinte, pondo de parte o Parnaso que cita Diogo do Couto até que não o sustente uma nova documentação, a poesia camoniana permaneceu inédita enquanto viveu o seu criador e, por consequência, sem se imprimir com o objecto de a dar aos leitores ${ }^{23}$.

Para o que interessa ao propósito do presente trabalho, a verdade é que tal como foi sempre publicada a obra lírica de Camôes, a utilizarem-se nas ediçôes tanto clássicas como contemporâneas os mais diversos critérios no atinente à ordenação das peças que a integrariam, inclusivamente o alfabético dos incipit em cada forma compositiva ou estrófica, como é o caso da Obra Completa organizada por Antônio Salgado Júnior ${ }^{24}$, as composiçóes camonianas mostram-se desorganizadas, de sorte que náo é possível realizar uma leitura sequencial ininterrompida para compreender como exprimem o sentido de um percurso vital ficcionalizado por meio do discurso poético. Deve-se ter em conta que a divulgação de textos petrarquistas em forma desordenada ou através de antologias modifica de maneira inevitável o seu sentido mais literal, porquanto isolam os

22 Para o episódio do roubo do Parnaso, vid. ainda Carolina Michaëlis de Vasconcelos, Estudos Camonianos. II, O Cancioneiro do Padre Pedro Ribeiro, Lisboa, Imprensa Nacional - Casa da Moeda, 1980, pp. 31-39. Reprodução fac-similada da $1^{a}$ ed. publicada em Coimbra pela Imprensa da Universidade no ano 1924.

23 Jorge de Sena escreveu decididamente: «Camöes quase inteiramente póstumo» (Jorge de Sena, "Camóes e os Maneiristas», em Trinta Anos de Camóes. 1948-1978 (Estudos camonianos e correlatos), vol. I, Lisboa, Ediçōes 70, 1980, p. 59).

${ }^{24}$ Luís de Camões, Obra Completa, Rio de Janeiro, G. B. Companhia Aguilar Editora, 1988. Organização, introdução, comentários e anotaçôes do Prof. Antônio Salgado Júnior. $1^{\mathrm{a}}$ reimpressão da $1^{\mathrm{a}}$ ed. de 1963. Salgado Júnior propóe uma regra de escassa complexidade que tenta harmonizar os variados critérios utilizados pelos editores camonianos precedentes. Essa resolução conciliatória funda-se, em primeiro lugar, na disposição das peças líricas em diferentes grupos respeitando consecutivamente a sua procedência em cada ediçáo donde são recolhidas, e, depois, no estabelecimento no interior desses mesmos grupos de uma ordem alfabética. Consegue-se com isso, pelos vistos, um posicionamento realmente neutral ao náo se fixar uma seriação que obedeça, como tinha ocorrido nomeadamente na Lírica Completa de José Maria Rodrigues e Lopes Vieira editada em 1932, apenas a uma tese interpretativa concreta dos versos amorosos do poeta: «Surgiu com isto novo problema: em que ordem dar essas composiçôes dentro de cada uma das partes? Já dissemos acima que tínhamos resolvido dar todas as composiçóes apresentadas pelos editores responsáveis posteriores a 1923. Claro que cada um deles tem também seu critério ordenador e não seria possivel reduzi-los a um só. Por outro lado, tais ordenaçóes são sempre o resultado dum ponto de vista pessoal, isto é, duma tese. Também nós insinuaríamos uma nossa no caso de darmos uma ordenaçáo diferente. Querendo ter nisto a maior imparcialidade, só tivemos possibilidade de uma solução aceitável: ordenar as composiçóes, dentro de cada uma das partes em que o processo tivesse aplicação, em seriação rigorosamente alfabética» (Salgado Júnior, ed., Luís de Camóes, Obra..., p. XVII). Salgado Júnior sugere, em qualquer caso, ainda uma outra proposta possível de estruturação da ordem dos poemas e até da obra literária completa de Camóes, integrando-se assim num mesmo conjunto tanto a vertente lírica quanto a épica, que dependeria de uma teorizaçáo explicativa geral sobre o processo de criação levado a termo pelo poeta. Embora se não cheguem a desenvolver completamente os resultados de tal hipotética teorização, para este editor, com efeito, é fácil de modo absoluto distinguir três ciclos sucessivos a respeito da literatura camoniana que podem facilitar grandemente a compreensão da sua natureza. Existiria inicialmente um ciclo caracterizado pelo domínio de uma preocupaçáo de essência sentimental, baseada no relato dos diferentes estados anímicos habituais, desde o namoro até à desesperança, numa biografia amorosa. Em seguida, poder-se-ia delimitar um segundo ciclo em que se revela, como nota marcante, a ligação das actividades lírica e épica, com interferências recíprocas constantes e inevitáveis. Por fim, coincidente com os últimos anos da vida do Poeta e já composto o poema épico Os Lusíadas, dar-se-ia um terceiro ciclo presidido pela volta à criação eminentemente lírica, mesmo que tingindo-se os versos ora da cor do pessimismo e da angústia em troca da confiança e da alegria do passado. 
textos respeito ao seu contexto, perturbando a compreensão que eles mereçam ${ }^{25}$. Neste sentido, é de esperar algum dia que uma edição para sempre rigorosamente definitiva da lírica de Camóes, quando as circunstâncias forem mais favoráveis ou, pelo menos, desfavoráveis em menor medida do que na altura presente, procure especialmente a colocaçáo de cada poema no lugar que lhe cumpriria dentro do conjunto editorial, além de resolver os problemas acostumados, que com certeza resultam de tâo árdua solução no caso concreto do autor de Os Lusiadas, de atribuir autorias certas, evitar leituras erróneas ou falsas e sugerir linhas interpretativas bem encaminhadas. E isto porque, indubitavelmente, a adequada ordenação dos textos líricos camonianos pode chegar a influenciar decisivamente na compreensão mais literal dos poemas para avaliálos com critérios estéticos numa análise esmeradamente correcta ${ }^{26}$.

Não é conveniente deixar sair da memória, como antes se sublinhou, o facto terminante de os poemas amorosos petrarquistas serem peças miúdas do vastíssimo mosaico construído por uma tradição literária, elevadamente normativizada, que se cimenta em idênticas ou muito semelhantes bases ideológicas, semânticas e formais. A ligação dialógica entre quase todos os textos pertencentes a tal tradição é evidente, e realiza-se através de uma complexa rede de relaçóes que se estabelece tanto a nível do código poético de que participam quanto no seio das próprias peças comparadas entre si, quer dizer, essa ligação citada é dupla e pode-se perceber simultaneamente de uma perspectiva paradigmática e sintagmática. Com efeito, o criador petrarquista trata de guardar um complexo equilíbrio, conforme as normas artísticas do tempo, entre o respeito à tradição, primacialmente encarnada em Petrarca, e o desejo compreensível de ultrapassar originalmente o modelo a que se consagra a imitaçáo, enquanto as peças líricas de um mesmo criador petrarquista, aliás, permitem advertir no plano da dispositio numerosos nexos entre elas de acordo com a feição típica de um canzoniere, os quais derivam da função que lhe é atribuída a cada composição como parte peculiar de um conjunto orgânico integrado por várias sequências de índole narrativa ${ }^{27}$. É manifesto que Petrarca ideou o seu Canzoniere como uma colectânea disposta com muito intensa coesão, e assim os fragmenta que o tornam inteiro apenas possuem o seu sentido mais satisfatório, que é de fundo unitário, quando contemplados reunidamente através de uma visão que considere todas as composiçóes como conjunto ${ }^{28}$. Em definitivo,

${ }^{25}$ Cfr. Silvio Avalle D’Arco, «I canzonieri: definizione di genere e problemi di edizione», em La critica del testo. Problemi di metodo ed esperienze di lavoro, Atti del Convegno di Lecce, Roma, 1985, pp. 363-382.

26 A propósito desta abrolhosa necessidade de serem devidamente dispostos os textos poéticos de estética petrarquista, vid. Alfonso Rey, "Criterios y prejuicios en la edición de la poesía de Quevedo en el siglo XIX», Edad de Oro, XIII (Primavera 1994), p. 133.

${ }^{27}$ No concernente ao modo de se sistematizarem a nível sintagmático as relaçôes que ligam os textos numa colecção de poemas que fazem parte de um canzoniere, vid. Marco Santagata, "Connessioni intertestuali nel Canzoniere del Petrarca», Strumenti Critici, 26, I (Febbraio 1975), pp. 80-112

28 «Está claro que el Canzoniere es la historia de un proceso vital, más o menos autobiográfico, medularmente centrado en una relación amorosa que exige la presencia de una amada a la que dirigirse y que, con su muerte, divide la historia en in vita $e$ in morte de la amada. Dentro de su relación con una obra total (importante en Petrarca), un cancionero es un sistema cerrado que (escribi historia) presenta un aspecto narrativo en el que van disponiéndose, según el orden del autor, las distintas composiciones, con su significación secuencial y el valor de distancia que señalan los espacios en blanco entre composición y composición" (Antonio Prieto, La poesía española del siglo XVI. I."Andáis tras mis escritos», Madrid, Cátedra, 1984, p. 33). 
o Canzoniere petrarquiano seria um exemplo magnífico de macrotexto literário onde todas as unidades textuais, mesmo a conservarem a sua própria identidade individual, patenteiam um alto grau de dependência temática e formal, não isenta de uma boa dose de narratividade ${ }^{29}$, verificável com relação às restantes unidades que fazem parte desta classe de colecção poética ${ }^{30}$.

É a sucessividade narrativa lógica que apresenta em especial qualquer canzoniere que exige um tipo específico de composição para desempenhar a importante função de preâmbulo dessa colecçáo poética. Eis o soneto-prólogo, um subgénero lírico intensamente codificado que resulta essencial no que diz respeito à unidade do canzoniere como repertório poético coesivo, já que fornece uma baliza inicial que justifica em grão medida a coordenação das demais peças num processo argumental coerente ${ }^{31}$. Este subgénero convencional da poesia petrarquista possui natureza de proémio ou prefácio, garantida pela sua posiçáo inicial privilegiada respeito aos poemas restantes, e costuma ser uma peça que se imagina desde uma fase do percurso humano do poeta dominado pela madureza sentimental, quando experimenta a convicção íntima e profunda de ter errado na força da paixão durante o tempo da juventude. Por isso é um tipo de composição com algumas notas em certo modo provenientes dos exempla medievais, cumprindo como um exordium retórico o papel de introdução ficcional na qualidade de anúncio resumido daquilo que figura nas partes consecutivas que completam o livro poético concebido como canzoniere.

Com efeito, a fonte primigénia deste subgénero lírico, o soneto petrarquiano «Voi ch'ascoltate in rime sparse il suono", que ocupa o primeiro lugar no Canzoniere, como nem podia deixar de acontecer, desempenha a função de fazer sobressair, desde o presente fingido da escrita dos poemas, que os fragmenta sucessivos se colocam numa altura pretérita plena de vấs ilusôes que não se corresponde com o arrependimento posterior do poeta ${ }^{32}$ :

"Voi ch'ascoltate in rime sparse il suono di quei sospiri ond'io nudriva 'l core

${ }^{29}$ Em concreto sobre a ideia de canzoniere como narraçáo, vid. G. Genot, "Strutture narrative della poesia lirica», Paragone, XVIII, 212 (1967), pp. 35-52; A. Jenni, «Un sistema del Petrarca nell'ordinamento del Canzoniere», em Studi in onore di Alberto Chiari, vol. II, Brescia, Paideia Editrice, 1973, pp. 721-732; Marco Santagata, Dal Sonetto al Canzoniere. Richerche sulla preistoria e la costituzione di un genere, Padova, Liviana Editrice, 1979; C. Segre, "Système et structures d'un canzoniere», em VV. AA., Recherches sur les systèmes signifiants, Paris, The Hague, Mouton, 1973, pp. 373-378.

30 Vid. Maria Corti, Principi della comunicazione letteraria, Milano, 1976, p. 146.

31 É importante destacar que a narratividade dos textos não procede de factores cronológicos, mas sobretudo do argumento da própria história que se constrói: "Lo esencial, pues, no es la cronología sino el orden narrativo dado (o pensado) por el poeta, que implica unas conexiones entre los textos y la posibilidad de leer cómo avanzan el argumento narrativo y una serie de sintagmas o mitos o predilecciones que definen la individualidad del poeta» (Prieto, La poesía española..., p. 33).

32 Para uma análise muito completa deste soneto preliminar no Canzoniere, vid. Raffaele Amaturo, Petrarca, Editori Laterza, 1971, pp. 248-251. Sobre a extraordinária funcionalidade, aliás, que possui o soneto inicial do Canzoniere petrarquiano com relação ao conjunto da obra, vid. Francisco Rico, "Rime Sparse. Rerum Vulgarium Fragmenta. Para el título y el primer soneto del Canzoniere», Medioevo Romanzo, III, 1 (1976), pp. 101-138. 
in sul mio primo giovenile errore

quando'era in parte altr'uom da quel ch'i' sono,

del vario stile in ch'io piango et ragiono

fra le vane speranze e 'l van dolore,

ove sia chi per prova intenda amore,

spero trovar pietà, nonché perdono.

Ma ben veggio or sí come al popol tutto

favola fui gran tempo, onde sovente

di me medesmo meco mi vergogno;

et del mio vaneggiar vergogna è 'l frutto,

e 'l pentersi, e 'l conoscer chiaramente

che quanto piace al mondo è breve sogno."33

A partir do exemplo original marcado por este soneto, em que se destaca a força do apelo moral aos leitores a fim de receberem atentamente e com proveito os versos que irão encontrar, é factível anotar em focagem diacrónica a voluntariedade de muitos poetas petrarquistas de incorporar um soneto com valor proemial às suas colecçóes líricas desde que lhes outorguem uma estrutura de canzoniere ${ }^{34}$. $\mathrm{O}$ investigador espanhol Juan Manuel Rozas tem delineado precisamente o percurso detalhado do soneto-prólogo a partir da sua origem na obra petrarquiana até às últimas amostras ${ }^{35}$, desvendando que se trata de um subgénero, de relevo crucial na história do petrarquismo peninsular, que com segurança alcançou enorme sucesso tornando-se mais rico de cada vez com os acréscimos semânticos que diversos autores apuseram ao modelo inicial. Antes de tudo, advirta-se que a influência posterior exercida pelo soneto "Voi ch'ascoltate in rime sparse il suono" foi em importante medida modificada sem muita demora por uma peça amorosa de extensão média do poeta catalão Ausiàs March, Qui no és trist, de mos dictats no cur, em que aparece na primeira oitava como novidade mais saliente o conceito de não se ocuparem dos seus versos aqueles que não sabem de amores nem

\footnotetext{
33 Jacobo Cortines, ed., Francesco Petrarca, Cancionero, vol. I, Madrid, Cátedra, 1989, p. 130.

34 Provavelmente tem sido António Ferreira o primeiro poeta português a utilizar na sua obra poética o conceito de canzoniere: "Ferreira foi o primeiro poeta verdadeiramente petrarquista em Portugal, porque foi o primeiro a escrever uma sequência de sonetos com uma estrutura muito parecida com a do canzoniere» (T. F. Earle, Musa Renascida (A Poesia de António Ferreira), Lisboa, Editorial Caminho, 1991, p. 122). Cfr. ainda o trabalho do mesmo autor "A Portuguese Sonnet Sequence of the Sixteenth Century", Bulletin of Hispanic Studies, LXIII (1986), pp. 225-234. Sobre a configuraçáo do modelo petrarquiano de canzoniere na obra de diferentes poetas espanhóis, mas com valiosas informações teóricas aplicáveis a autores petrarquistas de qualquer literatura, vid. G. Cabello Porras, "Sobre la configuración del cancionero petrarquista en el Siglo de Oro (La serie de Amarilis en Medrano y la serie de Lisi en Quevedo)", Analecta Malacitana, IV (1981), pp. 15-34; J. Lara Garrido, "Manierismo estructural y desarrollo manierista del signo en las Diversas Rimas de Vicente Espinel", em VV. AA., Estudios sobre Vicente Espinel, Anejos de Analecta Malacitana, 1, Málaga, Universidad de Málaga, 1979, pp. 17-30; Antonio Prieto, Garcilaso de la Vega, Madrid, S.G.E.L., 1975; "El cancionero petrarquista de Garcilaso», Dicenda. Cuadernos de Filología Hispánica, 3 (1984), pp. 97-115; "Con un soneto de Gutierre de Cetina», El Crótalon. Anuario de Filología Española, I, 1984, pp. 283-295.

35 Juan Manuel Rozas, «Petrarca y Ausías March en los sonetos-prólogo amorosos del Siglo de Oro», em Homenajes. Estudios de Filología Española, I (1964), pp. 57-75.
} 
tristezas, isto é, um apelo discriminante apenas aos leitores que tenham experimentado sofrimentos amorosos:

"Qui no és trist, de mos dictats no cur,

o $\mathrm{n}$ algun temps que sia trist estat,

e lo qui és de mals passionat,

per fer-se trist no cerque lloch escur:

llija mos dits mostrans penssa torbada,

sens algun art, exits d'hom fora seny,

e la raó quen tal dolor m'empeny

Amor ho sab, qui n'és causa estada."36

Além destas duas poesias que se acabam de transcrever, certamente os modelos mais transcendentais que servem de inspiração às realizaçóes ulteriores do subgénero soneto-prólogo, existem tanto na literatura portuguesa como na espanhola outros textos em quantidade numerosa que apresentam características semelhantes. Podem ser citados os sonetos de Diogo Bernardes cujos incipit são "Vos que d'amor cruel nunca sentistes» e "Aqui de largos males breve historia», em que se apela igualmente aos leitores para que a desgraçada história amorosa que lêem possa servir-lhes de exemplo, ou o soneto do mesmo autor cujo primeiro verso é "Cantei um tempo, agora choro a guerra», onde se contém uma chamada às musas para testemunharem a memória da sua desventura sentimental enquanto o Amor conservar o seu arbitrário poder ${ }^{37}$. Ou entre mais exemplos possíveis cabe trazer à baila "Nunca d'amor estuve tan contento", da autoria de Juan Boscán ${ }^{38}$, talvez o primeiro poeta peninsular a escrever um sonetoprólogo, assim como "Cuando me paro a contemplar mi estado», de Garcilaso de la Vega ${ }^{39}$, um poema de discutível adscrição ao subgénero, no entanto, já que não aparecem nele algumas notas normativas principais ${ }^{40}$, embora Fernando de Herrera, na qualidade de comentarista poético, numa altura quase coeva, o tivesse classificado

36 Rafael Ferreres, ed., Ausiàs March, Obra poética completa, vol. I, Madrid, Editorial Castalia, 1979, pp. 258-260.

${ }^{37}$ Aníbal Pinto de Castro, ed., Diogo Bernardes, Rimas Várias. Flores do Lima, Lisboa, Imprensa Nacional - Casa da Moeda, 1985, pp. 41-43. Reprodução fac-similada da edição de 1597.

38 Carlos Clavería, ed., Juan Boscán, Las obras de Juan de Boscán (De nuevo puestas al día y repartidas en tres libros), 2a ed., Barcelona, Promociones y Publicaciones Universitarias, 1993, p. 235. Além desta composição, Juan Boscán ainda seria autor de mais três sonetos-prólogo: «Las llagas que, d'amor, son invisibles», "Mas mientra más yo de 'sto me corriere» e "Quien terná en sí tan duro sentimiento".

39 Elias L. Rivers, ed., Garcilaso de la Vega, Poesías castellanas completas, Madrid, Editorial Castalia, 1972 , p. 37.

40 "Creo que por este morir inesperado, Garcilaso no preparó ningún soneto que funcionara como sonetoprólogo, como hizo Petrarca, y que es muy dudoso que pueda actuar como tal el "Cuando me paro a contemplar mi estado", (...)" (Prieto, La poesía..., p. 65). Para caracterizar o soneto garcilasiano "Cuando me paro a contemplar mi estado», Glaser utiliza o vocábulo rechenschaftssonett. Vid. Edward Glaser, "Cuando me paro a contemplar mi estado: trayectoria de un Rechenschaftssonett", em Estudios hispano-portugueses, Valencia, Editorial Castalia, 1957, pp. 59-95. 
como "prefación de toda la obra y de sus amores, y proposición con la contemplación y vista de lo presente y pasado» ${ }^{41}$.

Ora bem, no caso particular da obra lírica de Camóes torna-se possível advertir a presença de alguma composição que cumpra os requisitos genéricos do sonetoprólogo?

Sabido é compridamente o problema decisivo no tocante às dificuldades editoriais da poesia camoniana derivado da infeliz circunstância de o escritor só ter publicada em vida uma porção minúscula da sua lírica ${ }^{42}$. Conviria assinalar, com precisão, somente as seguintes três peças conhecidíssimas pela sua condição de éditas não postumamente: em primeiro termo, uma ode endereçada a D. Francisco Coutinho, Conde do Redondo e Vice-Rei da Índia, encomiando os Colóquios dos Simples e Drogas e Cousas Medicinais da India, de Garcia d'Orta, e que se contém nessa mesma obra de natureza científica publicada em Goa em $1563^{43}$; em segundo lugar, os tercetos "Despois que Magalhães teve tecida” e o soneto "Vós, Ninfas da gangética espessura" oferendados a D. Leonis Pereira e recolhidos na História da Provincia Santa Cruz a que vulgarmente chamamos Brasil, de Pero de Magalhães de Gândavo, que veio à luz em 1576 na oficina em que se imprimiram Os Lusiadas ${ }^{44}$; finalmente, até seria possível citar o soneto, embora muito duvidoso, "Ditosa pena, como a mão que a guia», intercalado sem nenhuma indicação autoral no tratado de caligrafia de Manuel Barata intitulado Exemplares de várias sortes de letras, de $1570^{45}$. É evidente, aliás, a carência de autógrafos a recolherem o espólio poético camoniano, um facto que reduz em grande medida a possibilidade de elaborar uma edição credora de toda a confiança.

Além destes obstáculos, que não permitem conhecer a disposição de cada peça que Camôes tivesse decidido para o conjunto da sua obra lírica tendo em conta o conceito

41 Antonio Gallego Morell, ed., Garcilaso de la Vega y sus comentaristas, 2a ed., Madrid, Editorial Gredos, 1972, p. 315.

${ }^{42}$ Cfr. Emmanuel Pereira Filho, As Rimas de Camóes - Cancioneiro de ISM, Rio de Janeiro, Companhia José Aguilar Editora - MEC, 1974, p. 219. Edição póstuma aos cuidados de Edwaldo Cafezeiro e Ronaldo Menegaz. Por seu turno, escreveu Klaus Dirscherl: "O facto de que ele não pôde mandar imprimir senão um número exíguo das suas poesias e de que também não as pôde publicar em forma cíclica tem feito até hoje do estabelecimento de um cânone seguro uma tarefa espinhosa: uma tarefa que não se torna mais fácil pelo facto de, desde a primeira edição póstuma de 1595, quase pertencer já à tradição da edição camoniana cada editor apresentar um novo cânone e, quase sempre obrigatoriamente ligadas a este, novas suposiçóes sobre a base histórica de alusões, temas, pessoas descritas" (Dirscherl, "Camóes e a tradição...", p. 38).

$43 \mathrm{Um}$ interessante estudo sobre esta «Ode ao Conde do Redondo» em concreto, dirigido a corrigir, restituindo-se o texto original, as muitas imperfeiçóes que houve na sua edição, é o de Maria Helena da Rocha Pereira, "Sobre o texto da Ode ao Conde de Redondo", Revista Camoniana, série 2a, VI (1984-1985), pp. 107-128. O texto da "Ode do Conde do Redondo" foi estabelecido excelentemente em edição crítica por Azevedo Filho. Vid. Leodegário A. de Azevedo Filho, "Ode a Conde do Redondo", de Luís de Camóes. Texto e estudo, Rio de Janeiro, Presença, 1988.

44 Sobre os poemas líricos de Camões não póstumos, vid. Roger Bismut, "Camões et son oeuvre lyrique», em VV. AA., Visages de Camóes, Paris, Fundação Calouste Gulbenkian, 1972, pp. 40-42.

45 Cfr. Leodegário A. de Azevedo Filho, Uma Visão Brasileira da Literatura Portuguesa, Coimbra, Livraria Almedina, 1973, p. 101. 
petrarquista de canzoniere, através de uma leitura minuciosa do universo ${ }^{46}$ sonetístico camoniano, na verdade seria factível registar, conquanto isso, a generosa cifra de doze possíveis peças a apresentarem elementos temáticos, mesmo que em variável proporção e com desigual ênfase, pertencentes ao subgénero soneto-prólogo. Os seus incipit, por ordem alfabética, são os seguintes: 1. "Com grandes esperanças já cantei», 2. "De Amor escrevo, de Amor trato e vivo", 3. "Depois de haver chorado os meus tormentos", 4. "Despois que quis Amor qu'eu só passasse», 5. "Em quanto quis Fortuna que tivesse», 6. "Eu cantarei do Amor tão docemente», 7. "Eu cantei já, e agora vou chorando», 8. "Já cantei, já chorei a dura guerra», 9. "Los que bivis subjectos a la estrella», 10. "Quando os olhos emprego no passado", 11. "Sospiros inflamados, que cantais» e 12. "Vós que escutais, en rimas derramado». É uma leitura particular e atenta à diacronia deste subgénero que deixa observar uma cifra como a indicada de sonetos-prólogo camonianos, mas existem indícios e provas suficientes de outra condição que vêm a confirmar esse cômputo. Não por acaso Agostinho de Campos, quando ordenou o seu Camóes Lirico ${ }^{47}$, chegou a distinguir uma série específica de sonetos, a primeira precisamente entre os oito grupos apresentados na sua edição, que denominou, com critério intuitivo, prologais, formado por seis textos dispostos alfabeticamente: "Despois que quis Amor qu'eu só passasse», "Emquanto quis Fortuna que tivesse", "Eu cantarei do Amor tão docemente», "No tempo que d'amor viver soía", "Pois meus olhos não cansam de chorar» e "Sospiros inflamados, que cantais" ${ }^{48}$.

Os argumentos mais seguros que confirmam a hipótese anunciada de existirem doze possíveis sonetos-prólogo são, no entanto, de natureza topológica, quer dizer, produto da análise realizável sobre a colocação de tais poemas em diversos documentos textuais tanto na tradição impressa como na tradição manuscrita, já que a situação preliminar desta classe de subgénero em concreto é, como acima se advertiu, uma das suas características mais salientáveis. Observa-se assim, em primeiro termo, que, no âmbito da tradição impressa, os sonetos com mais decisiva colocação em todas as ediçóes em que aparecem sem dúvida são «Em quanto quis Fortuna que tivesse» e «Eu cantarei do Amor tão docemente», visto como ocupam as posiçóes primeira e segunda

46 Com relação ao conceito de universo é preciso diferenciar o seu uso em oposiçấo ao conceito de corpus, tal como tem sublinhado convenientemente Leodegário A. de Azevedo Filho. Por universo interpretar-se-ia a ampla totalidade de poemas imputados a Camóes, ao menos uma vez e por qualquer motivo justificado ou não. O conceito de corpus estaria reservado, contrariamente, para aquela parte da totalidade de poemas referidos como camonianos que cabe discriminar com um elevado grau de confiança quanto à sua autenticidade. Vid. Leodegário A. de Azevedo Filho, "A Camóes o que é de Camóes", Revista Brasileira de Lingua e Literatura, 9 (1981-1982), pp. 13-24.

47 Agostinho de Campos, ed., Camóes Lírico, IV. Sonetos Escolhidos, Paris - Lisboa - Porto - Rio de Janeiro, Livrarias Aillaud e Bertrand - Livraria Chardron - Livraria Francisco Alves, 1926.

48 Agostinho de Campos tentava oferecer com essa pequena quantidade de composiçóes uma imagem realmente completa de Camóes como extraordinário cultor do género sonetístico, um intuito para o que adoptou ainda um critério de ordenação temática que busca agrupar os textos segundo os seus assuntos em oito secções: "Tendo de adoptar algum método no arranjo dêste quarto volume, optámos pela coordenação por assuntos, que facilita a procura dos poemas, além de ministrar melhor visáo crítica do carácter do Poeta. Vai assim o texto dividido em oito grupos, que sucessivamente intitulámos de: "Sonetos prologais»; "Filosofia do Amor»; "Madrigais»; "Despedidas e saüdades»; "Erros seus, má Fortuna»; "Amor ardente»; "Dinamene»; "Deus, Vida e Morte»» (Campos, "Introducção», em Camōes, Camóes Lírico, IV..., p. 9). 
já nas Rhythmas de 1595 e inclusivamente conservam esse privilégio em quase todas as ediçôes camonianas ulteriores ${ }^{49}$, até ao ponto de Agostinho de Campos mesmo avançar a suposição respeito a "Em quanto quis Fortuna que tivesse" de ser a prova, pelo seu tom proemial, que justificaria a verdade do roubo do Parnaso citado por Diogo do Couto ${ }^{50}$. Também os sonetos "Com grandes esperanças já cantei” e "Despois que quis Amor qu'eu só passasse” gozam de suficiente garantia topológica, porquanto ocupam os lugares terceiro e quarto nas Rimas de 1598, em que foram incorporados pela primeira vez ao património lírico camoniano. A propósito de «Com grandes esperanças já cantei», Faria e Sousa indica nas Rimas várias, aliás, alguns conteúdos próprios do soneto-prólogo, como a sensação final de sofrimento amoroso que transmite talvez como fruto de ser uma peça escrita nos últimos dias da existência de Camóes ${ }^{51}$, enquanto o mesmo editor julga sobre "Despois que quis Amor qu'eu só passasse", além de relacionar este soneto pelo seu tema com o anterior, que se trataria de uma peça também de cronologia tardia ${ }^{52}$.

Como se pode ver nos exemplos aduzidos, o magno hermeneuta Faria e Sousa é o editor camoniano que mais testemunhos fornece no que diz respeito aos poemas que acima se citaram pela sua condição de supostos sonetos-prólogo. Inclusivamente se exprime com maior definação em torno da propriedade preliminar dos sonetos restantes, uma vez que "Vós que escutais, en rimas derramado», por exemplo, imitação manifesta do "Voi ch'ascoltate in rime sparse il suono» como ele mesmo sublinha, está disposto na sua edição como primeiro do que denomina Centuria Segunda devido ao valor que mostra na qualidade de preâmbulo:

49 Só cabe indicar a excepção que se reflecte em 1932 quanto ao soneto «Eu cantarei de amor tẫo docemente», a figurar com o número 38, na edição da Lírica de José Maria Rodrigues e Afonso Lopes Vieira, decerto para ajustar o seu sentido à teoria amorosa do primeiro dos editores sobre a relação entre Camóes e a Infanta. Naturalmente, fica à margem do exame levado a cabo na edição Obra Completa arrumada por Antônio Salgado Júnior porquanto nela se utiliza, como já se disse, uma ordenação dos textos alfabética.

50 «Soneto evidentemente prologal ou introdutório, e como tal considerado por todos os editores e comentadores, que nêle vêem a prova indirecta do roubo do original manuscrito do Parnaso", mencionado por Diogo do Couto (Campos, ed., Camóes Lírico, IV.., p. 26).

51 Vid. Manuel de Faria e Sousa, ed., Luís de Camóes, Rimas várias, Lisboa, Imprensa Nacional - Casa da Moeda, 1972, pp. 8-13. O Visconde de Juromenha diverge de Faria e Sousa quanto à data de composição deste soneto: "Pensa Faria e Sousa que este soneto foi escripto nos últimos dias do Poeta; porém eu julgo que foi na India, e antes da morte da amante, porque aliás não exporia a idéa de arrependimento por ter chorado a morte da sua amada, o que é inteiramente contrario com as sentidas poesias que a esse asumpto escreveu» (Visconde de Juromenha, ed., Luís de Camões, Obras, vol. II, Lisboa, Imprensa Nacional, 1861, p. 364).

52 «Son dós los argumentos deste Soneto (como en el antecedente), uno de penas amorosas, otro de ingratitudes injustas con sus meritos: y llevalos por orden, porque primero fue enamorado, y por ello perseguido; $y$ despues fue buen soldado, y admirable Escritor; y en premio de todo se via morir a manos de la miseria, como al principio de essotro Soneto lo dijimos» (Faria e Sousa, em Camóes, Rimas..., p. 14). O Visconde de Juromenha arrisca ainda mais a cronologia provável desta composição: "Depois de ter experimentado das mãos do amor $e$ da fortuna toda a qualidade de tormentos, se contenta com declarar em verso os seus desvarios, e apresentar-se como exemplo. Este soneto foi escripto pela mesma ocasião da canção X, e acaba do mesmo modo que o final da mesma canção. Foi composto na India depois dos seus trabalhos, naufragios, prisão, e provavelmente da morte da amante» (Visconde de Juromenha, em Camôes, Obras, vol. II, p. 364). 
"Ya dixe sobre el Soneto 100 de la Cent. I y en el Prologo, que se imprimieron sin orden alguna estas Rimas: y la razon desto, y de no poder yo ordenarlas, como era menester en todo, y lo en que las puse en orden. Esta Centuria 2 de los Sonetos (conforme a aquella razon) pude ordenar, poniendo primero los amorosos, luego los tristes, luego los varios, luego los morales y sacros: porque como nunca fueron impressos los mas dellos, y los que lo fueron estavan muy viciados, y eran poco notorios, no avia el inconveniente de la mudança de los numeros, como allá diximos. Este Soneto es proposicion de los desta Centuria 2 y lo pudiera ser de todas estas Rimas, pues lo es de las de Petrarca, y el primero dellas, y mi Poeta gustò de traduzirle, y aviendolo hallado yo en un manuscrito le di este lugar." 53

É conhecido que a respeito da ordenação que têm todos os sonetos na sua edição, Faria e Sousa explica no final da I Centúria que os cem sonetos iniciais vão dispostos na mesma ordem com que apareceram na impressáo de 1598 por causa de estarem assim citados em vários escritos que se referem a eles e não provocar por isso inúteis confusôes. No entanto, clarifica ainda que a sua intenção é ordená-los depois por matérias segundo é o gosto do seu tempo, agrupando-os em amorosos, heróicos, morais e sacros:

53 Faria e Sousa, em Camôes, Rimas..., p. 193. Precisamente este poema é o primeiro dos últimos quarenta e três sonetos, integrados na "Terceira Série», que recolhe Álvares da Cunha na Terceira Parte das Rimas, um facto que salienta ainda o seu carácter introdutório. Com efeito, na "Terceira Série» reproduzem-se quarenta e três sonetos, todos eles completamente copiados ou, para melhor dizer ainda, saqueados da "II Centúria" da edição que fez Faria e Sousa através dos seus manuscritos inéditos, os quais aparecem respeitados na ordem original em que nesta fonte se relacionam, devendo-se indicar por outra parte que os intitulados "A morte, que da vida o nó desata», "Gentil Senhora, se a Fortuna imiga» e "Se me vem tanta glória só de olhar-te» foram já dados a conhecer com algumas variantes nas Rimas de 1616. É possível asseverar com toda a firmeza que é especialmente para esta "Terceira Série» que Álvares da Cunha, como já acima se disse, leu em parte os manuscritos em que Faria e Sousa arrumara as Rimas várias. Assim, dos primeiros sessenta e seis sonetos que integram a II Centúria nesta edição, Álvares da Cunha tirou proveito sem dúvida de quarenta e três, desprezando apenas aqueles recolhidos por Faria e Sousa que se continham sem variaçôes na edição de 1616, como por exemplo os poemas "Senhor João Lopes, o meu baixo estado", "Árvore, cujo pomo belo e brando», «O filho de Latona, esclarecido" ou, entre mais possíveis, "Por cima destas agoas, forte e firme», e também os que já estavam incluídos na "Primeira Série», como ocorre com os poemas "Esses cabelos louros e escolhidos», "Quem pudera julgar de vós, Senhora», "Onde porei meus olhos que não veja» ou "Que doudo pensamento é o que sigo". Com respeito a isto, no entanto, são muito surpreendentes na "Terceira Série» os casos dos sonetos «Eu me aparto de vós, Ninfas do Tejo» e "Que modo tão sotil da natureza!», já com a mesma versão editados respectivamente em 1595 e 1616 e publicados também identicamente por Faria e Sousa. Necessita-se apontar que a maneira diversa que presidiu à compilação dos sonetos da "Terceira Parte», um simples exercício de transcrição dos manuscritos de Faria e Sousa, é o que serviu a Costa Pimpão para amparar por contraste a excelente opinião que tem de Álvares da Cunha como editor no que respeita à "Primeira Série» e à "Segunda Série»: "Ao contrário, pois, do que se tem julgado, não é possivel colocar no mesmo pé, no ponto de vista crítico, e no que respeita à edição de 1668, os sonetos das séries $A$ e B, por um lado, e da série $C$, por outro. Esta, sendo mera transcriçáo de Faria e Sousa, tem este por único garante; e a admissão de cada um dos poemas da mesma série só pode fazer-se com cautelas infinitas, visto que, na melhor das hipóteses, sendo de Camöes, näo foi recolhido por aquele sem emendas profundas. Os sonetos comuns, das séries $A$ e B, têm, a seu favor, a presunção de terem sido reconhecidos como de Camóes por Álvares da Cunha e por Faria e Sousa, independentemente. É-lhes, por isso, devida maior confiança" (Costa Pimpão, "Introdução", em Camôes, Rimas, pp. LIII-LIV). 
“Esta primer Centuria vá por la misma orden que tiene en las Impressiones, en respeto de los numeros, considerando que por ellos andan citados estos Sonetos en varios Escritos; y quedarian erradas las citas si alterassemos los numeros; como era necessario se alterassen si pusiessemos los Sonetos por materias; como se usa oy, y como es razon que sea, poniendo primero los amorosos, despues los heroicos, luego los morales, y sacros. Esta orden guardê en la Centuria 2 porque los Sonetos que ella contiene no andan citados. Despues de puesta ella, en orden hallé otros manuscritos de que nuevamente cogi 64 Sonetos, y los puse por la misma orden." 54

Por seu turno, a posição sucessiva do soneto "De Amor escrevo, de Amor trato e vivo" nas Rimas várias com relação a "Vós que escutais, en rimas derramado", a ocupar assim a segunda posição nesta centena de poemas, assegura de modo semelhante o carácter introdutório que possui ${ }^{55}$, enquanto "Eu cantei já, e agora vou chorando", apesar de ser recolhido com o número 67 na I Centúria, Faria e Sousa o assinala como "prohemio de los [sonetos] tristes", destacando portanto a sua propriedade preliminar ${ }^{56}$. "Depois de haver chorado os meus tormentos" apresenta igualmente uma posiçâo excepcional nas Rimas várias, pois não precisamente em vão é o soneto inicial da "III Centúria», segundo razoa o editor seiscentista ao oferecer novas indicaçóes sobre a organização em que dispôs os poemas camonianos, depois de se lamentar de o escritor não ter dado ao prelo a sua obra lírica:

"Muchos regalos de entendimiento, y de buena orden en unas Rimas Varias, perdieron los entendidos, y amantes de la bien ordenada disposicion, en que mi Poeta no ubiesse dado a la estampa estas suyas: porque deste Soneto infiero yo que era proposicion de todos los que hizo a sus amorosas penas, y profundas tristezas, de que fue Pintor admirable. La orden (a mi parecer) era poner todos los amorosos debajo del primero con que entra la Centuria I. El con que entra la segunda, que es traducion del primero de Petrarca, era tambien propio para otra de los amorosos. Este con que doy principio a esta que llamo Tercera, claramente està mostrando que era para que a èl siguiessen (como dixe) los tristes tambien de materia amorosa. A estos se devian seguir los Varios a diferentes propositos; y luego los Morales, y Sacros. En la Centuria segunda he obervado esta orden; y no lo hize en la primera, por la razon que ya di en el Prologo. Hizelo en esta que llamo tercera asta el Soneto 46. Los que corren asta 64 hallê despues, y puselos assi como los fuy hallando: y allá daré la razon." 57

\footnotetext{
${ }^{54}$ Faria e Sousa, em Camôes, Rimas..., p. 191.

55 «El assunto deste Soneto es quanto el Poeta nació para ser amante, pues lo es sin ser amado, y sin reparar en los mortales peligros de tal suerte de Amor, que aun es más peligroso quando es mayor con excesso la Amada, qual era la suya para él, como luego veremos" (Faria e Sousa, em Camões, Rimas..., p. 195).

56 "He elegido este Soneto (por la proporcion que para esso tiene) por prohemio de los tristes que se siguen agora, aviendo dado fin a los amorosos, aun que estos tambien lo son en parte: êl es de los muy buenos de mi Poeta» (Faria e Sousa, em Camóes, Rimas..., p. 273). O Visconde de Juromenha aceita esse juízo de Faria e Sousa e comenta o tema do soneto: "Possuido de um certo scepticismo amoroso chora o tempo que cantou não contentamentos, mas confianças; não se queixará nem porá culpa ás esperanças, poisque a fortuna injusta é maior que os erros» (Visconde Juromenha, em Camóes, Obras, vol. II, p. 456).

${ }^{57}$ Faria e Sousa, em Camóes, Rimas..., p. 317.
} 
Por outra parte, Faria e Sousa faz sobressair a notável ligação do soneto «Já cantei, já chorei a dura guerra» com as composiçôes «Depois de haver chorado os meus tormentos», "Com grandes esperanças já cantei» e "Eu cantei já, e agora vou chorando», três possíveis sonetos-prólogo já analisados como possuidores de tal condição, mas o responsável das Rimas várias aponta ainda com mais nitidez a natureza proemial deste texto quando comenta os dois últimos versos da segunda quadra como palinódia, uma das notas essenciais do subgénero:

"De aqui se vè que el Poeta (a lo que parece) avia determinado cantar la Palinodia; esto es escribir otros tantos Poemas contra el Amor como por el avia escrito: y este Soneto venia a ser el Prohemio, ô introducción: y pudieran bien ir debaxo del algunos Sonetos que en estas Rimas ay, y otros versos en que predica desengaños de Amor." 58

A respeito das três peças restantes, Quando os olhos emprego no passado, Sospiros inflamados, que cantais e Los que bivis subjectos a la estrella, faz-se necessário dizer que Faria e Sousa assinala a influência exercida sobre a primeira pelo poema garcilasiano "Cuando me paro a contemplar mi estado", um hipotético soneto-prólogo como já se viu, até ao ponto de a composição camoniana reproduzir nas quadras as mesmas rimas que figuram naquele ${ }^{59}$, enquanto o Visconde de Juromenha lança a suposição de ser a segunda um soneto escrito numa fase de contemplação quase arrependida de apaixonados e lastimáveis amores passados ${ }^{60}$. O próprio Visconde de Juromenha, enfim, afirma que "Los que bivis subjectos a la estrella», poema que ele incorpora pela primeira vez à obra camoniana procedente do Cancioneiro de Luis Franco Correa, tem uma clara natureza introdutória como provável encabeçamento de uma quarta centúria de sonetos ${ }^{61}$.

Há suficientes indícios no âmbito da tradição impressa, como se pode comprovar, que validam o rótulo de sonetos-prólogo para as composiçôes assinaladas acima, um facto que se vê ainda ratificado com maior força ao realizar-se o labor de alargar a pesquisa àqueles documentos da tradição manuscrita que recolhem alguns desses poemas ${ }^{62}$. Por exemplo, além de se reproduzir nele a peça "Sospiros inflamados, que cantais" com o número quatro, "Com grandes esperanças já cantei” e "Depois de

\footnotetext{
${ }^{58}$ Faria e Sousa, em Camóes, Rimas..., p. 286. O Visconde de Juromenha também revela a natureza deste texto como soneto-prólogo: "Parece ser feito este soneto para proemio dos sonetos em que o Poeta cantava os desenganos de amor» (Visconde de Juromenha, em Camóes, Obra, vol. II, p. 461).

59 Vid. Faria e Sousa, em Camóes, Rimas..., p. 285. No entanto, Faria e Sousa destaca também a qualidade superior do soneto de Camóes respeito ao seu modelo.

60 «Este soneto bem se vê que foi feito depois de soffrimentos fortes nos seus amores; provavelmente já no tempo que estava na Índia» (Visconde de Juromenha, em Camóes, Obras, vol. II, p. 414).

61 «Soneto de introducção, provavelmente á quarta centuria de sonetos, que devia comprehender os derradeiros acontecimentos da sua inclinação amorosa, os quaes remataram com a morte da amante" (Visconde de Juromenha, em Camōes, Obra, vol. II, p. 491).

62 Desditosamente os sonetos «Depois de haver chorado os meus tormentos», «Eu cantei já, e agora vou chorando", "Quando os olhos emprego no passado» e "Vós que escutais, en rimas derramado» carecem de qualquer testemunho manuscrito.
} 
haver chorado os meus tormentos" são os sonetos iniciais no Appendix Rhythmarum ou Manuscrito Apenso, um documento que não viera suscitando tradicionalmente a atenção adequada entre os investigadores até que o infortunado camonista brasileiro Emmanuel Pereira Filho, em perseverante e exigente análise, provou que todos os sonetos que foram adicionados nas Rimas de 1598 têm aí a sua procedência básica ${ }^{63}$. "De Amor escrevo, de Amor trato e vivo" figura igualmente, no primeiro lugar, do Cancionero de la Real Academia de la Historia de Madrid ${ }^{64}$, um documento quinhentista de elevada utilidade em que estão recolhidas quarenta e três composiçóes camonianas, delas vinte e oito com autoria expressa e as quinze restantes com autoria indirecta ${ }^{65}$. Por sua vez, "Em quanto quis Fortuna que tivesse" também é o soneto que ocupa o posto primeiro no Cancioneiro de Cristóvão Borges ${ }^{66}$, um testemunho manuscrito extraordinário organizado em Lisboa no ano 1578, quer dizer, ainda em plena vida do escritor, onde figuram seis sonetos e três redondilhas explicitamente atribuídas a Camôes, além de outras sessenta e seis peças em certas áreas do manuscrito nitidamente peculiares ${ }^{67}$. "Já cantei, já chorei a dura guerra", por último, tem o terceiro lugar no "Índice" do Cancioneiro do Padre Pedro Ribeiro, utilíssimo documento textual copiado admissivelmente pela primeira vez em terras da Índia na altura de 1577 , isto é, também em vida do escritor ${ }^{68}$.

63 Vid. Emmanuel Pereira Filho, As Rimas de Camóes - Cancioneiro de ISM, Rio de Janeiro, Companhia José Aguilar Editora - Ministério da Educação e Cultura, 1974. Edição póstuma aos cuidados de Edwaldo Cafezeiro e Ronaldo Menegaz. Esta obra contém um fac-símile do Manuscrito Apenso acompanhado de lição diplomática. Custodiado na Biblioteca Nacional de Lisboa, hodiernamente o códice está encadernado como documento apenso a um exemplar das Rhythmas de 1595 que fazia parte da colecção do Cons. Thomaz Norton.

${ }^{64}$ Infelizmente não se tem por enquanto qualquer tipo de edição deste fértil manuscrito, conservado com a cota Ms. 12-26-8/D199 na Real Academia de la Historia de Madrid, só se podendo consultar através de cópia xerox.

65 Vid. Vítor Manuel de Aguiar e Silva, "Notas sobre o Cânone da Lírica Camoniana», Revista de História Literária de Portugal, III (1968-1972), p. 186.

66 Vid. The Cancioneiro de Cristóvão Borges, Berkeley, University of California Press, 1979. Edition and notes by Arthur Lee-Francis Askins.

${ }^{67}$ É muito perigoso e de graves consequências autorais, no labor de consulta de documentos manuscritos, o critério de se utilizarem como princípio de atribuição textual as denominadas áreas ou zonas mais ou menos pertencentes por deduçáo a um poeta concreto. Repare-se na perspicácia da seguinte reflexáo de Víctor Infantes sobre esse assunto: "La existencia probada de manuscritos ha permitido establecer que esta poesía se difundió así, en el cuaderno al gusto, copiado de otro, añadido con otras copias, aumentado con el tiempo; creaba un libro unitario, personal y particular para la lectura paciente y detenida, pues todo copista es lector real de lo que transmite. La carencia casi unánime de manuscritos autógrafos o completos de la obra de un solo autor (...) y de nuevo generalmente en copias tardias (...) que parecen revelar una paciente labor interesada de la ordenación de los papeles, se compensa con el códice misceláneo, por estrofas, por temas, por cronologías, por ubicaciones geográficas, a veces, por simple capricho; es, sin duda, el característico del periodo" (Infantes, "En busca del lector...», p. 146).

68 Carolina Michaëlis realizou um esplêndido estudo e uma impecável reprodução diplomática desse “Índice”. Vid. Michaëlis de Vasconcelos, Estudos camonianos, II: O Cancioneiro do P. Pedro... A ela nomeadamente se deve o mérito de contestar de modo firme as calúnias que Faria e Sousa lançara a respeito de Diogo Bernardes. Ainda sobre a obra de Diogo Bernardes e os seus vínculos autorais com a de Camóes, vid. Pinto de Castro, «Nota introdutória», em Bernardes, Rimas Várias, pp. 7-23. 
Contudo parece muito difícil aceitar que as doze composiçôes resenhadas pertençam sem nenhuma classe de dúvida a Camôes, e nem podia deixar de acontecer essa circunstância desde que uma cifra tão elevada de sonetos-prólogo converteria na verdade o autor de Os Lusíadas num caso anómalo, tendo em conta a história do subgénero através da poesia petrarquista europeia. Com efeito, há provas generosas relativamente a alguns sonetos, embora com diverso nível de gravidade, que obrigam a condiderá-los suspeitos ou duvidosos para integrarem um corpus de absoluta confiança autoral. Deve-se dizer nesse sentido que o momento actual da Camonologia apresenta, graças às propostas editoriais de Leodegário A. de Azevedo Filho, uma conjuntura extraordinária para possuir, porventura pela primeira vez em quatrocentos anos de difícil história, um ponto de partida sólido e seguro que permita obter uma imagem fidedigna de Camóes como lírico ${ }^{69}$. Este camonista brasileiro, fiel continuador da linha de investigação aberta por Emmanuel Pereira

${ }^{69}$ Além de muitos artigos de enorme interesse em volta da poesia camoniana, é preciso salientar que a materialização mais extraordinária dessas propostas é ainda o monumental plano editorial que Azevedo Filho tem até agora em pleno processo de elaboração, a Lírica de Camóes, em vários volumes. Deles já vieram a lume no presente os dois primeiros, destinados respectivamente, por um lado, a questôes teóricas de índole geral que atingem a lírica do autor de Os Lusíadas, e, por outro, à editoração das peças do género sonetístico que fazem parte do cânone mínimo, sendo de recente publicação o primeiro tomo do terceiro volume, correspondente às cançôes. Vid. Luís de Camóes, Lírica de Camóes. 1. História, metodologia, corpus. Texto estabelecido à luz da tradiçấo manuscrita, em confronto com a tradição impressa, por Leodegário A. de Azevedo Filho. Apresentação de António Houaiss. Revisão editorial e colaboração na adaptação ortográfica de Sebastião Tavares de Pinho, Lisboa, Imprensa Nacional - Casa da Moeda, 1985; Lírica de Camóes. 2. Sonetos, t. I. Apresentação de Sílvio Elia, Lisboa, Imprensa Nacional - Casa da Moeda, 1987; Lírica de Camóes. 2. Sonetos, t. II, Lisboa, Imprensa Nacional - Casa da Moeda, 1989; Lírica de Camóes. 3. Cançóes, t. I, Lisboa, Imprensa Nacional - Casa da Moeda, 1995. O bosquejo previsto do projecto editorial de Azevedo Filho ainda observa a publicação de outros quatro volumes. Assim, o volume quarto incluirá os tercetos e as oitavas; o volume quinto, as éclogas e as sextinas; no volume sexto figurarão as redondilhas; por fim, o volume sétimo há-de ser um glossário com um índice analítico de todo o vocabulário da lírica de Camóes. Necessita-se dizer, no entanto, que é altamente provável que estes sete volumes já realizados ou inicialmente conjecturados se vejam afinal excedidos. Com certeza, a Lírica de Camóes é uma assombrosa obra feita com sumo desvelo e em muitas ocasióes tendo-se de ultrapassar com valentia os numerosos riscos inerentes à própria matéria estudada, mas, não obstante isso, há que indicar convictamente que Azevedo Filho tem assumido com alta responsabilidade esses mesmos riscos para conseguir oferecer um valiosíssimo instrumento que é, decerto, de uso imprescindível em qualquer abordagem analítica da lírica de Camôes. Um dos maiores acertos do seu projecto editorial consiste, precisamente, em perceber com clareza as razóes que explicariam os resultados pouco satisfatórios, ou pelo menos não absolutamente dignos de aprovação, das iniciativas que tiveram lugar ao longo da história das ediçôes camonianas e até das teorizaçóes modernas construídas com o mesmo alvo, sempre concentradas quase exclusivamente no exame obstinado e monótono da tradição impressa. Na realidade, perante esse quadro tão escassamente esclarecedor, o que Azevedo Filho propóe como valiosa premissa essencial é o sistemático regresso aos cancioneiros quinhentistas, decerto as fontes onde se acha em estado mais puro a genuína voz do Poeta, com o objecto, em primeiro termo, de constituir um corpus seguro, e, depois, de confrontar rigidamente as liçôes que neles se referem e as que procedem da tradição impressa. A partir dessa tarefa, é fácil de ver, o seguinte e mais importante objectivo tem de residir na revisão diligente e profunda, do ponto de vista tanto autoral quanto textual, de toda a poesia de carácter lírico atribuída alguma vez a Camóes, de modo que em última instância esta nova edição possa fornecer, como uma contribuição capital que sirva de base sólida para estudos ulteriores de pendor literário, textos com garantia a respeito da sua autenticidade assim como da sua fidedignidade. 
Filho $^{70}$, dá um novo impulso às teorias que aquele expusera incompletamente, trazendo à colação mais códices com grande teimosia crítica para reconstituir o genuíno cânone de Camóes e para reproduzir os textos consoante a sua pureza original. À vista disso parece indubitável que as condiçóes actuais exigem necessariamente não adiar a tarefa urgente de caracterizar a prática literária do escritor na sua vertente lírica com maior nível de segurança, já que é possível dispor felizmente, após um árduo trabalho prévio desenvolvido com todo o rigor pelo Prof. Azevedo Filho, de uma ampla colecção de sessenta e cinco sonetos, a integrarem o "Índice Básico de Autoria", que constituem um material poético garantido tanto do ponto de vista autoral quanto textual, susceptível de ser reputado, em suma, como um campo de análise que fica alheio ao perigo de elaborar exames críticos sobre composiçôes que não têm o selo da autenticidade.

Com relação aos supostos doze sonetos-prólogo que se apontaram acima, é possível advertir, assim, que "Com grandes esperanças já cantei”, "De Amor escrevo, de Amor trato e vivo", "Despois que quis Amor qu'eu só passasse” e "Já cantei, já chorei a dura guerra” têm contestada a sua autoria camoniana hipotética. O primeiro soneto, acrescentado pela primeira vez à obra lírica do escritor nas Rimas de 1598 com origem no Manuscrito Apenso, aparece atribuído a Diogo Bernardes no "Índice" do Cancioneiro do Padre Pedro Ribeiro ${ }^{71}$, enquanto o segundo soneto, publicado pela primeira vez na

${ }^{70} \mathrm{O}$ acto inicial das pesquisas ecdóticas de Pereira Filho sobre a lírica de Camóes tem a sua apresentação pública nas sessóes desenvolvidas durante o I Simpósio de Lingua e Literatura Portuguesa, que se celebrou no Rio de Janeiro no ano 1967. Com a leitura da valiosa comunicação "Aspectos da Lírica de Camões (O Problema do Cânone)», o jovem estudioso começa a procurar, munido de uma excepcional cultura filológica, assinaladamente no campo da investigação textual, o estabelecimento do que possa ser um critério objectivo e rigoroso com o intuito de delimitar a autoria camoniana autêntica dos textos que através de séculos de acréscimos foram atribuídos ao Poeta, e para o qual, aliás, propóe um plano de actuaçấo crítica resolutamente inovador que é de suma severidade. Assim, o seu ponto de partida reside na clara convicçấo de ser praticamente impossível manter a ideia tradicional de cânone como a quantidade absoluta de poemas escritos por Camões, já que a fragilidade dos dados documentais a respeito disso não permite sequer contemplar tal alvo coleccionador. Ao invés, em sua opiniấo deve ser substituído esse pensamento que se faz inatingível pela necessária interpretação do conceito de cânone, neste caso, como a soma de elementos textuais possuintes da capacidade suficiente para fornecer afinal a feição de Camóes na qualidade de poeta lírico. Vid. Emmanuel Pereira Filho, "Aspectos da Lírica de Camóes (O Problema do Cânone)", trabalho publicado originalmente em Atas do I Simpósio de Língua e Literatura Portuguesa, Rio de Janeiro, Gernasa, 1968, pp. 143-158. Depois recolhido em Estudos de crítica textual, Rio de Janeiro, Gernasa, 1972; edição póstuma aos cuidados de Leodegário A. de Azevedo Filho. E também em As Rimas de Camóes..., pp. 271-281. Além do método crítico que elaborou para esclarecer a questão autoral da lírica de Camóes, é preciso citar outros seus trabalhos, publicados postumamente, como a edição diplomáticointerpretativa, acompanhada da reprodução fac-símile do códice, do Appendix Rhythmarum ou Manuscrito Apenso a um exemplar da edição de 1595 das Rhythmas (vid. Pereira Filho, As Rimas de Camóes..., pp. 15-210), ou a leitura crítica da canção “Tão suave, tão fresca e tão fermosa”, antes dele explicada sempre de modo errado como uma ode por todos os editores camonianos (vid. Emmanuel Pereira Filho, Uma forma provençalesca na lírica de Camóes, Rio de Janeiro, Gernasa, 1974; edição póstuma aos cuidados de Leodegário A. de Azevedo Filho).

${ }^{71}$ Embora apresente a sua autoria contestada, o editor Hernâni Cidade julga camoniano este soneto por não figurar impresso como obra de Diogo Bernardes nem haver constância de que este reclamasse a paternidade. Vid. Hernâni Cidade, ed., Luís de Camóes, Obras completas. Poesia Lírica, 5a ed., vol. I, Lisboa, Sá da Costa, 1985, p. 243. Por não confiar muito no "Índice» do Cancioneiro do Padre Pedro Ribeiro", Jorge de Sena também o considera de autoria camoniana segura: "Como se está vendo, o indice de Pedro Ribeiro (que ele mesmo é um dos poetas indiculados) não é um primor de segurança e de cuidado. Quer-nos parecer que 
Terceira Parte das Rimas de Álvares da Cunha, do qual Faria e Sousa declara aliás que o encontrou com algumas variantes num manuscrito sob a autoria de Luís Álvares Pereira ${ }^{72}$, está consignado no Cancioneiro de Cristóváo Borges com o nome de Francisco de Sá. "Despois que quis Amor qu'eu só passasse", impresso originalmente nas Rimas de 1598 procedente do Manuscrito Apenso, de novo surge no Índice do Cancioneiro do Padre Pedro Ribeiro sob a autoria de Diogo Bernardes ao mesmo tempo que "Já cantei, já chorei a dura guerra" 73 , publicado inicialmente por Faria e Sousa, o último texto pertencente ao grupo de sonetos-prólogo com autoria controversa.

Além dos quatro sonetos citados, é possível determinar a existência de mais cinco composiçóes sem qualquer prova de autoria camoniana devido sobretudo à carência de documentos manuscritos que as recolham: "Depois de haver chorado os meus tormentos", "Eu cantei já, e agora vou chorando", "Los que bivís subjectos a la estrella”, "Quando os olhos emprego no passado" e "Vós que escutais, en rimas derramado". Nesse grupo cumpre destacar o caso especial do penúltimo soneto, atribuído a Camóes

mais vale - e nem sempre - como confirmação relativa de uma autoria do que como base absoluta para uma exclusão categórica; e foi segundo esse critério que o usámos ao estudarmos os sonetos de 1595" (Jorge de Sena, Os Sonetos de Camóes e o Soneto Quinhentista Peninsular, 2a ed., Lisboa, Edições 70, 1980, p. 71). E Jorge de Sena acrescenta: "O soneto é atribuido a Bernardes pelo Padre Ribeiro e náo está, como tantos outros que lhe são atribuidos, nas suas obras impressas. E não figura no Cancioneiro Luís Franco Correa (onde, de resto, só os agrupamentos que reconhecemos autorais são indício, já que as atribuiçóes marginais são ulteriores)" (Sena, Os Sonetos de Camóes..., p. 73).

72 "En un manuscrito hallé este Soneto en nombre de Luis Alvares Pereyra, persona de conocida nobleza, y poca dicha para Poeta, como lo mostró en aquel Poema suyo intitulado Elegiada, en que llora la perdida del Rey Don Sebastian. Y tuvo animo para escribirle y publicarle a los ojos de Luis de Camóes: osadia que tambien aconteciô a Geronimo Corte Real con su volumen en verso suelto de la memorable Lepanto. $O$ atrevimientos de la humana ceguedad! Mas dexado esso el Soneto está alli por de Luis Alvarez, pero muy differente. Escuso copiarle; $y$ digo desde luego que en este Tomo, y en los siguientes he de traer muchas cosas que andan en Impressiones $y$ manuscritos por de mi Poeta, y de otros Escritores. Pero destas no traeré sino las que a toda buena luz parecieren: y tengalas cada qual por de quien fuere su gusto; que quando sean de otro, él recivirá esta honra de que las tengamos por de Camóes; y el Letor nos deve agradecer el darle este luzido entretenimiento" (Faria e Sousa, em Camốes, Rimas..., p. 196). Como se vê, Faria e Sousa revela a propósito deste soneto que o encontrou reproduzido numa fonte manuscrita indeterminada sob o nome de Luís Álvares Pereira, um poeta para ele de tão infeliz qualidade literária que jamais poderia ser o seu autor. O mais importante não está, porém, na justificação que o exegeta seiscentista desenvolve em concreto sobre a possível contestação autoral que concerne à peça "De Amor escrevo, de Amor trato e vivo", mas na atrevida advertência, confessada não sem candura, de que vai puxar para Camóes muitos poemas semelhantes ao seu estilo que em obras impressas e em cancioneiros aparecem atribuídos a outros poetas. Dando-se a conhecer que a lírica camoniana estava em boa parte prejudicada pela sua dispersão, e por conseguinte originando um problema de índole muito aberta, Faria e Sousa ainda acaba por dizer que tal manobra de atribuir ao seu Poeta versos que acaso pertenceriam a autores diferentes seria apenas uma honra para eles e que, afinal, tudo há-de ficar por conta do parecer deliberativo dos leitores.

73 Este soneto chegou a ser impresso como obra de Diogo Bernardes, mas através de uma versão com numerosas variantes. De facto as interpretações que merecem inclusivamente podem ser diferentes, pois "o soneto de Diogo Bernardes (...) encaminha-se para uma solução religiosa: a guerra contra (e com) o Amor leva à certeza de que só a Deus se deve amar. O soneto camoniano (?) se encaminha, não em direção a Deus, mas às Musas, a cujo templo o Poeta consagrará a sua lira. São, evidentemente, dois caminhos divergentes que partem de um ponto comum" (Cleonice Berardinelli, ed., Luís de Camóes, Sonetos de Camóes. 'Corpus' dos Sonetos Camonianos, Paris -Rio de Janeiro, Centre Culturel Portugais - Fundaçâo Casa de Rui Barbosa, 1980 , p. 597). 
por Faria e Sousa depois de avisar que o encontrou redigido em espanhol com a autoria do Conde de Vimioso num manuscrito ${ }^{74}$, assim como a circunstância que atinge a "Los que bivís subjectos a la estrella" de figurar registado no Cancioneiro de Luis Franco Correa sem indicação de autoria, donde o tirou o Visconde Juromenha para acrescentá-lo à obra camoniana.

Tendo em conta as dificuldades autorais que se acabam de expor em breves linhas, pode-se concluir que tão-só as peças "Em quanto quis Fortuna que tivesse", "Eu cantarei do Amor tão docemente" e "Sospiros inflamados, que cantais", as quais fazem parte dos sessenta e cinco sonetos agrupados no Índice Básico de Autoria do Prof. Azevedo Filho $^{75}$, oferecem garantias razoáveis de pertencerem com fidedignidade a Camóes, de tal modo que apenas estas irão constituir o objecto da análise. E isso porque resulta imprescindível para realizar qualquer exame de tipo hermenêutico, além de muito útil, tomar como ponto de partida textual um conjunto poético canónico digno do maior crédito quanto à sua genuidade. É conveniente lembrar a inexactidão ou a parcialidade de análises literárias que sejam feitas a partir de composiçóes apócrifas e de autoria incerta, bem como de textos deficientes e erróneos.

Visto isso, pode-se dizer quanto ao primeiro poema seleccionado que "Em quanto quis Fortuna que tivesse" apresenta como característica notável a circunstância de ser um autêntico soneto-prólogo em que se cumpre a maioria dos requisitos que singularizam este peculiar subgénero temático da poesia de feição petrarquista. Entre tais requisitos tópicos, lembre-se, cabe citar a utilização preferencial da forma sonetística, a colocação destacada respeito às outras composiçóes que formam o conjunto poético em que

\footnotetext{
${ }^{74}$ Com o alvo de deitar por terra a influência exercida pelo camonista seiscentista na tradição impressa ulterior, Aguiar e Silva repara neste caso que robustece sem lugar a dúvidas a opiniấo de Faria e Sousa ser um imprudente editor que vai longe demais no processo de fixação textual camoniana. Este investigador tem analisado, de tal maneira, o que acontece com o soneto "Quando os olhos emprego no passado" como notável exemplo que se mostraria bastante elucidativo da forma tão limitadamente recomendável de Faria e Sousa se conduzir sempre que assentar uma lição. Além da demonstração de não pertencer na verdade a Camóes nem ser em origem redigido sequer em português, Aguiar e Silva comprova claramente, no tocante a esse soneto, que nas leituras que Faria e Sousa fornece estão introduzidas múltiplas correcçóes que vão desde arranjos léxicos ou substituiçôes vocabulares até a importantes modificações métricas. Tal comportamento deixa transparentar, em opiniáo de Aguiar e Silva, que o propósito habitual de Faria e Sousa seria sobretudo lavrar os versos com toda a teimosia, voltado como ele estava para o almejo de melhorar aquelas deficiências que de modo absolutamente impressionista chegasse a perceber indignas do estro camoniano. Vid. Aguiar e Silva, "Notas sobre o Cânone...», pp. 188-201. Convém advertir que, na análise conjunta feita por Aguiar e Silva desta composição e do soneto "Nunca em amor danou atrevimento", predomina entre as conclusôes que se tiram o impulso de retirar a Faria e Sousa a autoridade editorial que teve no passado e, ao mesmo tempo, de validar a decisão de Costa Pimpão, enquanto editor camoniano, votando ao desprezo as liçóes do responsável das Rimas várias para acreditar mais nas que Álvares da Cunha proporciona no mesmo século XVII. Veja-se, assim, o que em definitivo afirma Aguiar e Silva quanto ao soneto "Nunca em amor danou atrevimento": "Eis agora, em breves palavras, o que nos parece poder-se concluir do que atrás ficou exposto. Em primeiro lugar, pensamos que é necessário excluir da lírica camoniana o soneto "Nunca em amor danou o atrevimento"; em segundo lugar, verifica-se que os factos e os problemas por nós analisados confirmam, mais uma vez, a pouquissima ou nenhuma confiança que merece Faria e Sousa como editor de Camóes. O que expusemos acerca do soneto acima citado confirma ainda, de modo bem claro, a justeza do critério editorial adoptado pelo Prof. Costa Pimpão relativamente aos sonetos que aparecem em lição comum nas ediçóes de Álvares de Cunha e Faria e Sousa» (Aguiar e Silva, «Notas sobre o Cânone...», pp. 201-202).

75 Vid. Azevedo Filho, Lírica de Camóes. 1. História,..., pp. 248-254.
} 
aparecem, a invocação ao leitor como companheiro nos tormentos que o Amor causa mais do que como juiz literário, a influência de certos modelos fixados por Petrarca e Ausiàs March, o desejo, enfim, de servir de escarmenta para outros e, além disso, não se deve esquecer um requisito de carácter formal procedente do uso comum da rima em -ento nesta classe de sonetos ${ }^{76}$. De facto, "Em quanto quis Fortuna que tivesse" parece uma peça escrita com posterioridade a fim de figurar como preâmbulo adequado de uma colecção de poemas com assunto amoroso previamente escritos ${ }^{77}$, e poder-se-ia pensar mesmo que o soneto teria sido elaborado para começar uma provável reunião de poemas dispostos numa ordem determinada, como um canzoniere à maneira petrarquiana, que reflectisse o desenvolvimento do processo amoroso vivido pelo emissor lírico. A evidente natureza introdutória deste soneto foi notada regularmente por todos os editores camonianos, fazendo que aparecesse, já desde as duas primeiras colecçóes dadas ao prelo no século XVI, no primeiro lugar da série de composiçóes que arrumavam. O próprio Faria e Sousa manifesta a qualidade introdutória do texto e expôe, aliás, um quadro bastante aproximado do subgénero soneto-prólogo traçando com linhas muito ajustadas a sua história:

"Este Soneto es la proposicion de estas Rimas; y la màs elevada que yo hallo en todos los Autores de semejantes Poemas. Parece que con dezir esto me obligava a copiar aqui las de los mejores. Escûsolo, por no despender tiempo en cosas que no sirven a la explicacion a que me expongo; y más quando estoy viendo que esto solo me harâ ser bastante dilatado, aunque no he de dezir más de lo preciso: y tambien porque los eruditos lo pueden examinar, sino quisieren dar credito a este nuestro juizio. Petrarca es el primero que propuso en forma sus varias Rimas; y despues le imitaron el Bembo, el Casa, y otros quedandole inferiores. Nuestro Magisterio Garcilasso no ordenò las suyas para estamparlas, y si llegâra a hazerlo no fuera sino con todo acerto. Quien las ha publicado eligió de sus Sonetos el que realmente era más propio para el principio. Lope de Vega imitó bien a Petrarca, empeçando Versos de Amor, conceptos esparzidos. Yo en mi Parte I que consta de seis Centurias de Sonetos, de cada una hize proposicion, por la variedad dellos; y tambien en las seis partes que se siguen, confórme a las materias, procurando imitar a los Maestros."78

Esse carácter proemial de "Em quanto quis Fortuna que tivesse" faz que os seus argumentos estejam concebidos para servir de escarmenta, provada na experiência

\footnotetext{
76 Vid. Juan Manuel Rozas, "Petrarquismo y rima en -ento», em A. Porqueras Mayo e C. Rojas, eds., Filología y crítica hispánica. Homenaje al Prof. Federico Sánhez Escribano, Madrid, Ed. Alcalá - Emory University, 1969, pp. 67-85. Assim, é visível que «Em quanto quis Fortuna que tivesse» apresenta nas rimas das quadras os vocábulos contentamento / pensamento e isento / tormento, bastante frequentes nos sonetosprólogo petrarquistas estabelecendo uma equação sentimental muito nítida que identifica no amor a paixão e a mágoa.

77 Tendo em vista o conjunto da obra camoniana, o soneto foi qualificado por Helder Macedo como «o pórtico mais adequado de toda a sua poesia lírica» (Helder Macedo, Camóes e a Viagem Iniciática, Lisboa, Moraes Editores, 1980, p. 11).

${ }^{78}$ Faria e Sousa, em Camóes, Rimas..., p. 1.
} 
própria, perante aqueles que verdadeiramente amam, mostrando-se-lhes assim os perigos que encerra qualquer paixão. Com efeito, no tempo em que o emissor lírico ainda contemplava a esperança de alguma felicidade, a sua vontade amorosa levou-o a escrever poemas em que ficavam descritos os numerosos efeitos que tal sentimento nele provocava. Contudo, o Amor logo temeu que esses poemas pudessem revelar os seus enganos a alguma pessoa ingénua ou desnorteada e é por isso que decidiu eclipsarlhe a inspiração com distintas mágoas. $\mathrm{O}$ amante chama a atenção enfaticamente, em qualquer caso, de todos os que estáo dominados por um desígnio amoroso e advertelhes que os poucos versos que irão ler somente contêm límpidas verdades:

"Em quanto quis Fortuna que tivesse esperanças de algum contentamento, o gosto de um suave pensamento me fez que seus efeitos escrevesse.

Porém, temendo Amor que aviso desse minha escriptura a algum juízo isento, escureceo-me o engenho, com o tormento, pera que seus enganos não di[ss] es[s]e.

Ó vós, que Amor obriga a ser sujeitos a diversas vontades, quando lerdes num breve livro casos tão diversos!

Verdades puras são, e não defeitos; e sabei que, segundo o amor tiverdes, tereis o entendimento de meus versos."79

A primeira quadra faz referência aos dias do passado do amante em que a excelente disposição da sua ventura, ainda boa naquele tempo, permitia que tivesse esperanças de alcançar a satisfação que provém do amor correspondido ${ }^{80}$. Era uma altura em que o emissor lírico, convertido aqui em autor implicado como responsável fictício da elaboraçáo material dos poemas, sentia a necessidade de cantar através

79 Azevedo Filho, Lírica de Camóes. 2.Sonetos, t. I, p. 275.

80 "Quando esperava gustos amorosos le obligò el gusto desta esperança a que escribiesse efetos de Amor. Esta esperança le fue concedida por la Fortuna, y luego abaxo dirà que a ella se le opuso el Amorn (Faria e Sousa, em Camốes, Rimas..., p. 2). Sem reparar no carácter tópico que possui dentro do fundo temático da poesia petrarquista o jogo temporal derivado da contemplação arrependida do passado desde a desesperada perspectiva do presente, Agostinho de Campos sugeriu que este soneto teria sido composto por Camóes nos últimos anos da sua vida: "Os versos 1 e 2 fazem supor que êste Soneto foi escrito tarde, numa idade em que o Poeta estava já descrente e cansado de desilusóes» (Campos, em Camóes, Camóes Lírico, IV..., p. 26). Aliás, Agostinho de Campos interpretou também de modo impressionista o sintagma um suave pensamento, supondo que desvendaria o facto de "Em quanto quis Fortuna que tivesse" estar concebido para servir de prólogo somente às peças inspiradas por uma dama isolada: "Êste modo de dizer parece indicar que a compilação poética a que o Soneto havia de servir de Prólogo continha produçóes referentes a uma única inspiradora» (Campos, em Camões, Camóes Lírico, IV..., p. 26). 
da escrita ${ }^{81}$ as emoçóes que tal sentimento lhe fazia experimentar, pois que a dita da doce paixão o convidava a esse acto. Porém o Amor, temeroso de que a sua mensagem servisse de fonte de conhecimento para os que ignoravam com inocência os seus enganos, tirou-lhe de súbito a inspiração, deixando à sua alma apenas a mágoa.

Após a descrição dessa fase pretérita do seu amor, o emissor lírico, transformado de novo em autor implicado, dirige nos dois tercetos uma dramática invocação aos leitores que são os destinatários dos seus poemas. Apelados exclamativamente com a apóstrofe pronominal expressa vós, eles hão-de se sentir obrigados pelo Amor a sujeitar-se a um desejo afectivo ao lerem os acidentes tấo dissímiles que a paixão pôde mostrar através do seu breve livro. Porque os conteúdos dos versos não se apresentam como sentimentos fingidos ${ }^{82}$, mas como autênticas vivências ${ }^{83}$, e assim, segundo forem capazes de experimentar o amor, os leitores poderão obter em igual medida a compreensão das emoçôes que neles se recolhem ${ }^{84}$.

Dois sintagmas deste soneto têm sido especialmente problemáticos na história crítica da poesia camoniana, dando lugar a exageradas interpretaçóes, baseadas em pouco sólidos fundamentos, que atingiram em concreto à própria constituição do cânone do escritor ${ }^{85}$, por um lado, e à obstinação dos biógrafos e dos investigadores por tirar episódios verídicos da ficçáo dos poemas, por outro. Desta maneira, devese assinalar em primeiro termo que a expressão breve livro, referida supostamente à

${ }^{81}$ A propósito do termo escriptura, Cleonice Berardinelli diz que «em Camóes tem sempre o sentido de texto escrito, obra, poema» (Berardinelli, ed., Sonetos de Camóes. 'Corpus'..., p. 499).

${ }^{82}$ Deve-se ter em conta que o significado da palavra defeitos no v. 12, em oposiçáo semântica a verdades puras, é o de "desvio, afastamento da verdade, fantasia» (Maria de Lurdes Saraiva, ed., Luís de Camóes, Lírica completa, vol. II, Lisboa, Imprensa Nacional - Casa da Moeda, 1980, p. 14). À margem de qualquer fundamento textual documentado, e acaso forçado por uma interpretação errónea do último terceto, há que dizer que Wilhelm Storck propôs que defeitos fosse substituído por conceitos, já que com tal vocábulo, em seu entender, o verso teria melhor sentido. Vid. Wilhelm Storck, ed., Luís de Camōes, Sämmtliche Gedichte, t. II, Pederborn, Druck und Verlag von Ferdinand Schöningh, 1880-1885, p. 367.

${ }^{83}$ É uma hipérbole quase imprescindível em certos poetas petrarquistas conceder aos versos uma maior aparência de sinceridade: "Ante los tópicos y falsedades del petrarquismo, es necesario intensificar los conceptos, como los colores se intensifican en la conocida linea-Garcilaso, Herrera, Góngora-; es necesario demostrar que la tragedia amorosa de cada imitador es mayor que la de todos los modelos que ha tenido presentes" (Rozas, «Petrarca y Ausías...», p. 67).

${ }^{84}$ A elucidação do significado dos dois versos últimos do soneto é aproveitada por Faria e Sousa para estabelecer uma avaliação comparativa das obras de Petrarca e Camóes, indicando isso a circunstância de existir, desde o primeiro momento, a vontade de se destacar a originalidade da poesia camoniana perante os seus mais ilustres modelos: "Agora se declara, y dize que el entendimiento de sus versos amorosos en quien los lee, ha de ser a medida del amor que tuviere. Si no fuere amante le parecerán mal; si amare algo, algo le pareceran; y pareceranle razonablemente si con mediania amare; y amando finamente le pareceran finissimos. De aqui resulta para quien entiende lo que es Amor, y la expression de sus efectos, no avra Poesia tan alta en materia amorosa, como la de Petrarca, y esta de mi Maestro, que tengo por ventajoso; porque en todo el no le cede, y en lances le excede con gran distancia. Es verdad que el Petrarca se queda con la Primazia; cosa más considerable: mayormente quando los que le han sucedido no pueden dar un passo sin él» (Faria e Sousa, em Camóes, Rimas..., p. 3).

${ }^{85}$ Cumpre sublinhar, em tal sentido, que a presença da palavra livro no v. 11 tem sido utilizada inclusivamente como prova para justificar a veracidade do testemunho de Diogo do Couto sobre o roubo do fabuloso Parnaso, porque Camóes estaria a referir-se a ele neste soneto. 
extensão da obra lírica de Camóes, serviu nomeadamente a Faria e Sousa para justificar a imaginativa crença de o poeta ter tido somente a intenção de publicar uma parte menor da sua produção, precisamente a de melhor qualidade, deixando os piores versos sem os dar ao prelo ${ }^{86}$. Em segundo lugar, há que frisar devidamente que a expressão verdades puras, lida ao pé da letra e sem se contrastar com o código ideológico da poesia petrarquista, tem sido julgada em numerosas oportunidades como um indício certo de a lírica camoniana se poder interpretar em função de pressupostos autobiográficos. Consoante tal perspectiva crítica de índole abertamente subjectivista, os versos de Camóes estariam redigidos com toda a sinceridade, fornecendo um testemunho verdadeiro da existência vital da figura do escritor susceptível de ser crido até nos menores detalhes que se confessam ao longo da sua obra. Como é possível notar, segundo esta concepção que esquece gravemente já o fingimento como traço essencial da criação literária, tratar-se-ia de interpretar os argumentos dos poemas camonianos em chave meramente existencial, mesmo extraindo daí aqueles dados biográficos que a ausência de suficientes documentos fidedignos não permite conhecer.

No que diz concretamente respeito a esta questão de grande relevo, torna-se necessário advertir, porém, que a pretensão de veracidade suma, contida poeticamente no sintagma verdades puras oposto a defeitos, está inscrita numa corrente tópica de natureza específica na lírica petrarquista que tem a ver com o desejo de aparentar, de modo abertamente fictício, que as confissóes sentimentais do emissor lírico se podem identificar com as próprias vivências do autor que as escreve. A interpretação que Aguiar e Silva realizou do controverso desenlace deste poema sublinha esse sentido de uma perspectiva restritamente literária e alheia a qualquer tentação biografista. Para ele, efectivamente, a mensagem dos dois versos últimos, em harmonia com a poética da imitatio vitae petrarquista, estabeleceria uma relação de equilíbrio entre a fingida verdade que o emissor lírico proclama e o apelo à solidariedade sentimental que se pede ao receptor dos poemas ${ }^{87}$.

86 "No es breve este libro, aunque son diversissimos los assuntos, y los casos. Pero desto se puede inferir que el P. no determinava publicar quanto avia escrito deste genero, sino lo que tuviesse por mejor. En la primera Edicion fue más breve: en las otras creciò un poco: y en esta es más otro tanto que en ellas, como se puede ver de lo que diximos en el Prologo; y las razones porque damos a la estampa todo lo que dêl se ha descubierto; aunque algunas cosas no sean de tan elevacion» (Faria e Sousa, em Camóes, Rimas..., p. 3).

87 «Se a criação poética se autentica e ganha fundura humana pela sua ligação originária e substantiva com as verdades puras existencialmente vividas pelo amante sujeito da enunciação lírica, de análogo modo a recepção dos textos assim produzidos se encontra condicionada e regulada pelo substrato das experiências vitais do amor que os seus eventuais leitores possuam» (Aguiar e Silva, "Aspectos petrarquistas...", em VV. AA., Cuatro lecciones..., p. 111). De resto, ainda que com insuficiente firmeza talvez, Klaus Dirscherl confirma de maneira análoga a inconveniência de aplicar à poesia de Camôes leituras críticas biografistas que tomam como ponto de partida a interpretação literal do sintagma verdades puras, já que se trata de um indiscutível estilema da lírica de raiz petrarquiana que inclina a crer que não necessariamente os argumentos poetizados se têm de referir à própria vida do poeta que os cria: «Portanto um valioso documento biográfico? É possível. Em todo o caso o que não pode passar despercebido é que estes versos recebem o seu sentido, em primeiro lugar, do contexto em que se encontram. São argumentos num soneto que Camóes evidentemente concebeu como introdução a um ciclo de poemas por ele planeado, mas depois possivelmente nunca editado em forma de livro. As convençóes que se estabeleceram para este tipo de poesia depois do Canzoniere de Petrarca, e as quais evidentemente utiliza, são assim pelo menos tão importantes para o sentido dos seus versos como a eventual relação destes com factos da vida do poeta» (Dirscherl, "Camôes e a tradição...», pp. 38-39). 
Essa ilusão literária, de alcance geral no extenso âmbito da poesia proveniente do modelo fundado por Petrarca, faz-se ainda mais patente como um elemento fulcral do subgénero que constitui o soneto-prólogo e das suas convençóes temáticas. Decerto é suficiente levar a cabo um confronto superficial de "Em quanto quis Fortuna que tivesse" com poesias da mesma natureza de mais autores, designadamente de Petrarca e Ausiàs March, para se dar conta da importância que encerram as semelhanças de tipo semântico que guardam entre si ${ }^{88}$. E em definitivo, como não deixa de resultar compreensível, essas mesmas semelhanças obrigam a desconfiar da tentação de acometer a leitura dos versos camonianos em chave puramente biografista. Embora não seja conhecido nenhum modelo concreto que Camóes pudesse ter imitado em "Em quanto quis Fortuna que tivesse", existem várias composiçóes em que é perceptível a presença de indubitáveis analogias. A fonte do subgénero que se fixa com o soneto-prólogo encontra-se certamente em Petrarca, em particular no soneto "Voi ch'ascoltate in rime sparse il suono", o qual ocupa o primeiro lugar, como proémio poético, no seu Canzoniere. A coincidência mais importante entre este soneto e "Em quanto quis Fortuna que tivesse" corresponde ao uso do vocativo pronominal vós para se referir aos leitores, convertendo-se assim as duas peças numa evidente invocação a eles como destinatários dos poemas. Além disso, também é notória a similitude marcada pela focagem temporal que permite ao emissor lírico contemplar os dias do passado desde o arrependimento do presente, determinando isso que os versos se apresentem como escarmenta amorosa para outros. Mas para lá do modelo primigénio fornecido por Petrarca, o poema camoniano oferece igualmente certas reminiscências do soneto de Boscán "Nunca d'amor estuve tan contento", sobretudo no que atinge à utilização da forma vós, que precisamente aparece no mesmo lugar nas duas peças, isto é, no começo do primeiro terceto, ao realizar-se a apóstrofe aos leitores:

"Nunca d'amor estuve tan contento que ' $n$ su loor mis versos ocupasse; ni a nadie consejé que s' engañasse buscando en el amor contentamiento.

Esto siempre juzgó mi entendimiento: que d' este mal tod' hombre se guardasse, y assí, porque 'sta ley se conservasse, holgué de ser a todos escarmiento.

¡O! vosotros que andáys tras mis escritos gustando de leer tormentos tristes, segun que por amar son infinitos,

mis versos son deziros. "iO benditos los que de Dios tan gran merced huvistes que del poder d'amor fuéssedes quitos!» 89

${ }^{88}$ Cfr. Rozas, "Petrarca y Ausiàs March...», p. 67.

89 Clavería, ed., Juan Boscán, Las obras..., p. 235. 
Aliás, "Em quanto quis Fortuna que tivesse" até exibe alguns ecos dos versos iniciais da composição de Ausiàs March "Qui no és trist, de mos dictats no cur", acima transcrito, designadamente no que diz respeito ao convite que se faz aos leitores para que leiam os textos consoante a intensidade do seu próprio sentimento amoroso $^{90}$. Por último, resulta ainda possível destacar algumas afinidades evidentes entre a composição de Camóes e o soneto de Hernando de Acuńa "Huir procuro el encarecimiento". Com efeito, uma leitura atenta dos dois textos consente delimitar como comuns o motivo temático derivado da intenção de poetizar apenas verdades e não enganos ou o argumento que procede do desejo de servirem os versos próprios como escarmenta perante os leitores:

"Huir procuro el encarecimiento, no quiero que en mis versos haya engaño,

sino que muestren mi dolor tamaño cual le siente en efeto el sentimiento.

Que mostrándole tal cual yo le siento será tan nuevo al mundo y tan extraño, que la memoria sola de mi dańo a muchos pondrá aviso y escarmiento.

Así, leyendo o siéndoles contadas mis pasiones, podrán luego apartarse de seguir el error de mis pisadas

y a más seguro puerto enderezarse, do puedan con sus naves despalmadas en la tormenta deste mar salvarse." ${ }^{\prime 1}$

Com uma boa parte também das características genéricas que pertencem à forma do soneto-prólogo, na composição "Eu cantarei do Amor tão docemente" realiza-se o canto ao Amor, sublimando a sua essência através da possibilidade de a recolher em poesia. $\mathrm{O}$ mesmo Faria e Sousa, implicitamente, torna saliente nos seus comentários a natureza desta composição como soneto-prólogo, pondo-a em relação com o soneto "Em quanto quis Fortuna que tivesse" 92 . O editor das Rimas várias estabelece como possível modelo deste

${ }^{90}$ Sobre as relaçốes literárias que ligam Camôes e Ausiàs March, vid. Nilva Mariani Gallo, "A concepção do amor em Camões e Ausiàs March", Revista Camoniana, série 2a, IV (1981), pp. 67-91.

${ }^{91}$ F. Díaz Larios, ed., Hernando de Acuña, Varias Poesías, Madrid, Cátedra, 1982, p. 89.

92 "El soneto I [ Em quanto quis Fortuna que tivesse»] fue proposicion en general hablando con el Auditorio; este lo es en particular de los efetos que resultarán de su canto, y de qual sea el sugeto dèl con quien empieça a hablar» (Faria e Sousa, em Camóes, Rimas..., p. 5). A partir da mera leitura deste poema, aliás, é preciso relembrar que Agostinho de Campos lançou a conjectura biografista de Camóes pretender a organização de uma espécie de canzoniere dedicado a uma única dama: «No entanto a composição não tem defeitos formais e é literariamente muito importante, porque mostra o propósito de organizar uma 
poema camoniano o soneto de Petrarca "Io cantarei d'amor sí novamente", chamando a atenção para o facto de esta peça preambular inserir-se com o número 102 no seu Canzoniere $^{93}$. Com efeito, é factível comprovar com facilidade as afinidades que existem entre os dois textos, mas deve-se dizer que estas se reduzem principalmente ao que tem a ver com a estrofe inicial segundo se aprecia mediante a leitura do soneto petrarquiano:

"Io cantarei d'amor sí novamente ch'al duro fiancho il dí mille sospiri trarrei per forza, et mille alti desiri raccenderei ne la gelata mente;

e 'l bel viso vedrei cangiar sovente, et bagnar gli occhi, et piú pietosi giri far, come suol che degli altrui martiri et del suo error quando non val si pente;

et le rose vermiglie infra la neve mover da l'òra, et discovrir l'avorio che fa di marmo chi da presso 'l guarda;

e tutto quel per che nel viver breve non rincresco a me stesso, anzi mi glorio

d'esser servato a la stagion piú tarda." 94

compilação metódica de poesias consagradas a uma só inspiradora, o que dá razão àqueles que querem achar, para entendimento da Lírica de Camôes, o fio de um alto e único amor» (Campos, em Camóes, Camóes Lírico, IV..., p. 193). Cfr. ainda José Maria Rodrigues, Camóes e a Infanta D. Maria, Coimbra, Imprensa da Universidade, 1910, p. 42.

93 «Imitacion del 102 de Petrarca, que aviendo ordenado sus Rimas, no sé yo con que fundamento quiso que fuesse 102 el Soneto que pudiera ser primero, o segundo, por ser proposicion; porque a la mitad del libro dezir: Yo cantaré de amor tan nuevamente, teniendo ya cantado tanto dèl poco proposito tiene» (Faria e Sousa, em Camóes, Rimas..., p. 5).

${ }^{94}$ Cortines, ed., Francesco Petrarca, Cancionero I, p. 484. A circunstância de o soneto de Camóes não prosseguir após a quadra inicial a imitatio com respeito à fonte do poeta italiano foi bem advertida por Hernâni Cidade: "A imitação, porém, não vai além desta primeira quadra, em Camóes mais artisticamente constituida, em Petrarca com mais vigorosa expressáo. Nestas restantes estrofes, segue o lusitano via diversa. Enquanto o mestre se detém na ideia de comover de amor aquela que ama, o seu discípulo enuncia os vários temas que o amor sugere e, relativamente à mulher, não é o desejo de comovê-la que exprime, mas a certeza de que, para lhe cantar o gesto, lhe falta "saber, engenho e arte" (Hernâni Cidade, Luís de Camóes. O Lírico, Lisboa, Editorial Presença, 1984, p. 123). Igualmente Maria de Lurdes Saraiva frisou no mesmo sentido a independência argumental ulterior de "Eu cantarei do Amor tâo docemente": "A 1a estrofe adapta a de um soneto de Petrarca: "Io cantarei d'amor si novamente / ch'al duro fianco il di milli sospiri / trarrei per forza, e milli alti desiri / raccenderei nella gelata mente". Logo a seguir, Camóes afasta-se do modelo petrarquista, e faz poesia própria» (Saraiva, ed., Camôes, Lírica..., vol. II, p. 15). Cumpre não esquecer, porém, que o último verso do soneto de Camóes ainda se inspira no fecho do soneto "Quella per cui con Sorga ò cangiato Arno" (CCCVIII) de Petrarca (Cortines, ed., Francesco Petrarca, Cancionero II, p. 882):

"Le lode mai non d'altra, et proprie sue,

che 'n lei dur come stelle in cielo sparte, 
No poema camoniano propriamente se acham ligados o louvor do Amor e o louvor da dama, em ordenada sucessão primeiro nas quadras e depois nos tercetos, mas o traço temático predominante que se observa no desenvolvimento argumental do texto é exactamente o compromisso de se empregar a poesia para glorificar o Amor por meio da apresentação das emoçóes mais evidentes que ele faz sentir. $\mathrm{O}$ emissor lírico faz prometimento de cantar com extrema doçura o Amor utilizando fórmulas de feitura harmoniosa, para obrigar a sentir aqueles que não experimentam a força emotiva que nasce dos sinais mais visíveis que se podem perceber no sentimento amoroso. Ele há-de fazer manifesto o Amor perante o olhar de todos os que escutem o seu canto, descrevendo os numerosos gestos atenciosos que a paixáo suscita. Esses gestos cuja exposição precisa se anuncia são nomeadamente as pequenas e suaves raivas, os lamentos que se proferem desleixadamente, o tímido atrevimento e a mágoa da ausência, todos eles a constituírem emoçóes habituais da pessoa que ama. Além disso, o emissor lírico faz também promessa de cantar a dama que ele adora, dizendo poucos pormenores em especial do recatado desdém com que corresponde à declaraçáo do seu amor. Reconhece ainda com toda a modéstia, contudo, que não há-de pronunciar o canto que à partida gostaria de fazer, porque confessa humildemente que carece de sabedoria, génio e talento para louvar a elevada e maravilhosa feição da dama:

"Eu cantarei do Amor tão docemente, per uns termos em si tão concertados, que dous mil acidentes namorados faça sentir ao peito que não sente.

Farei o Amor a todos evidente, pintando mil segredos delicados, brandas iras, sospiros descuidados, temerosa ousadia e pena $\mathrm{a}[\mathrm{u}]$ sente.

Também, Senhora, do d[e]spre[z]o honesto de vossa vista branda e rigurosa, contentar-me-ei dizendo a menor parte.

Porém, $\mathrm{p}[\mathrm{e}] \mathrm{ra}$ cantar de vosso gesto

a composição alta e milagrosa, aqui falta saber, engenho e arte."95

Talvez a característica mais saliente deste soneto seja, como acima se disse, a associação concertada do elogio do Amor e do elogio da dama que o emissor lírico

pur ardisco ombreggiare, or una, or due:

ma poi ch'i' giungo a la divina parte

ch'un chiaro et breve sole al mondo fue,

ivi manca l'ardir, l'ingegno et l'arte."

95 Azevedo Filho, Lírica de Camóes. 2.Sonetos, t. I, p. 325. 
promete cantar transformado em verdadeiro autor implicado, segundo sublinham com grande ênfase as marcas gramaticais que ocorrem de início nas duas primeiras estrofes, "Eu cantarei do Amor» e "Farei o Amor». De acordo com esse esquema temático, nos quartetos ele realiza o anúncio da execução do canto ao Amor de um modo muito comovedor, traçando em termos bem proporcionados a natureza de todos os sintomas que apresentam os namorados para, com tais exemplos, provocar que experimentem o mesmo fenómeno amoroso aqueles que se mostram insensíveis ${ }^{96}$. Como fica indicado na quadra segunda, é a sua intenção, efectivamente, evidenciar perante outros a totalidade das diferentes reacçóes que o Amor promove, comunicando-as de modo explícito através da escrita. No oferecimento do emissor lírico estão indicados diversos efeitos, porventura como modelos escolhidos do que logo se poderá encontrar ao longo do seu canto, e assim se citam em enumeração tetramembre, nos dois últimos versos desta estrofe, as iras, os suspiros ${ }^{97}$, as ousadias e a saudade na distância, que procedem da vivência do sentimento amoroso.

Se a primeira parte da peça, concentrada nos quartetos, está consagrada a recolher a promessa do canto ao Amor, nos tercetos muda-se o destinatário do encómio que o emissor lírico apresenta, o qual agora é a sua dama. Em qualquer caso, convém advertir que o canto à dama não se deve considerar de forma independente, já que se acha integrado, como uma circunstância natural, no próprio canto ao Amor. Conforme revelam as regras do canto poético amoroso, de uma perspectiva geral torna-se preciso que o emissor lírico disponha de uma amada que se converta em instrumento para a exposição dos acidentes que nascem do Amor, e é por isso que no primeiro terceto figura uma apóstrofe à dama em que se declara que ela irá ser também o objecto da sua escrita. Porém, faz-se adequado reparar no facto de o emissor lírico modificar agora até certo ponto o tom do seu anúncio, já que a firmeza reflectida nos quartetos quanto à sua capacidade para levar a cabo o canto se transforma neste momento em humildade, por causa do alto carácter da mulher amada ${ }^{98}$. Assim, o emissor lírico declara em primeiro termo que tão-só irá cantar especialmente os aspectos positivos do seu amor pela dama, dizendo ${ }^{99}$ muito pouco da rigorosa e honesta serenidade com

\footnotetext{
${ }^{96}$ Faria e Sousa exagera a importância do significado que se contém no v. 5 e faz sobressair a índole maravilhosa do amor sentido realmente por Camóes: "Mi P. conoció bien quan Maestro era en la escritura amorosa, y assi pudo con gran seguridad dezir esto; porque no avrá quien tenga sentimiento humano que leyendo estos sus Poemas amorosos no se sienta assaltado de Amon» (Faria e Sousa, em Camóes, Rimas..., p. 6).

97 O v. 7 apresenta até três palavras em rima diferentes nos diversos testemunhos que recolhem este soneto. Assim, no Cancioneiro de Cristóvão Borges, escolhido por Azevedo Filho como texto-base, pode-se ler descuidados, enquanto nas duas reproduçōes do texto que estão no Cancioneiro de Luís Franco Correa aparecem as liçóes descuidados e cansados. No que diz respeito aos documentos da tradição impressa, tanto nas Rhythmas quanto nas Rimas várias surge a versão magoados. Cfr. Azevedo Filho, Lírica de Camóes. 2.Sonetos, t. II, pp. 328 e 333.

98 Cfr. Maria Vitalina Leal de Matos, O canto na poesia épica e lírica de Camóes. Estudo de isotopia enunciativa, Paris, Fundação Calouste Gulbenkian - Centro Cultural Português, 1981, p. 499.

99 A pertinente anotação semântica de Faria e Sousa quanto à acção verbal dizendo no v. 11 revela que o vocábulo se deve interpretar como sinónimo de cantando: "Estâ aqui por cantando, como claramente se ve de lo con que entra "Eu cantarey y" de lo con que fenece "porém para cantar", como si al dezir, "dizendo", ubiera dicho, "cantando"; si no fuesse esto assi, dixera "diziendo la menor parte, pero para dezir" (Faria e Sousa, em Camóes, Rimas..., p. 7).
} 
que ela corresponde às suas solicitaçóes amorosas ${ }^{100}$. Aliás, é no terceto segundo que acrescenta modestamente a falta de aptidão para celebrar com dignidade as elevadas e admiráveis virtudes da mulher que adora, por causa de o emissor lírico não possuir saber, engenho e arte, segundo se adverte no desfecho do soneto ${ }^{101}$.

Na última composição qualificada como de carácter prologal, "Sospiros inflamados, que cantais", é exequível apreciar com clareza o propósito de se apresentarem aos leitores as criaçóes próprias como experto aviso acautelado. Trata-se de uma nova palinódia poemática com alguns traços pertencentes ao subgénero soneto-prólogo em que o amante, como manifesto responsável da escrita dos textos na qualidade de autor implicado, se arrepende dos seus antigos erros passionais e solicita que o resto das peças sejam compreendidas de uma perspectiva exemplar e instrutiva ${ }^{102}$. Numa altura em que a morte já não está longe como remédio da doença amorosa, neste caso o emissor lírico dirige-se aos seus versos com a apóstrofe sospiros inflamados, dizendo-lhes que o seu destino há-de ser ficar neste mundo como ilustração perante outros dos males que a vivência do amor origina. Desta maneira, lendo uns escritos em que se patenteiam os prejuízos que causa um sentimento falso, eles conhecerão as manobras traiçoeiras do Amor e da Fortuna sofridas por uma experiência alheia ${ }^{103}$ :

100 "Honesto desprecio en dòs maneras: una por defensa de la honestidad que es singularissima joya de la mayor belleza; otra, porque es tambien perfecion della el despreciar con modestia al pretendiente; ni es muger noble, ni entendida la que le desprecia con palabras, o acciones descorteses haziendo gran ruido por alguna demonstracion amorosa» (Faria e Sousa, em Camóes, Rimas..., p. 6).

${ }^{101}$ Apesar de o verso último constituir uma declaração de modéstia de carácter tópico, Faria e Sousa tenta tirar o sentido profundo de o emissor lírico não dispor de capacidade para gabar a elevada feição da amada: "Todavia dize que si bien hará con su musica que ame quien no ama, ès tan sublime el objeto della que para los ojos llegará todo el caudal del saber, ingenio, i arte, quando mucho a dezir la menor perfeccion dellos; pero que todo queda incapaz en llegando a querer dezir la admirable composicion deste rostro y cuerpo: esto es lo proporcionado y sereno del semblante, y de la estatura, y lo ayroso della» (Faria e Sousa, em Camóes, Rimas..., pp. 7-8). Parece adequado relembrar a primeira estrofe de "La fábula de Narciso" de Hernando de Acuña, em que o emissor lírico também confessa que a sua escassa aptidão poética não é suficiente para celebrar as altas excelências da dama (Díaz Larios, ed., Hernando de Acuña, Varias..., p. 91):

"Si un bajo estilo y torpe entendimiento

merecieran llegar a aquella altura

do, señora, llegó mi pensamiento,

y tuviera en esto igual ventura,

pudiera yo contar lo que es sin cuento,

dando a vuestro valor y hermosura

seguridad, cual nadie la ha tenido,

de la ofensa del tiempo y del olvido."

102 Não obstante isso, Wilhelm Storck julgou que, em vez de prólogo, o soneto poderia ser melhor contemplado como um epílogo poético, composto de caso pensado para fechar a colecção de peças amorosas criadas por Camôes. Cfr. Storck, ed., Camôes, Sämmtliche..., t. II, p. 383. Em certa forma, é possível ligar essa consideração do erudito alemão com o seguinte juízo de M. a Vitalina Leal de Matos em volta do texto: "Soneto "testamentário", por assim dizer, já que, perante a situação de morte iminente, se dirige à obra em conjunto, impondo-lhe um sentido último, e, para além deste sentido, a encarrega de uma mensagem" (Leal de Matos, O canto na poesia..., p. 501).

103 Nas anotaçóes que Faria e Sousa dedica a este poema, pode-se ler um surpreendente trecho em que o editor seiscentista e escritor desvenda a sã inveja com que examina em muitas ocasióes o alcance estético da obra camoniana. Assim, em clara lisonja à categoria literária do Poeta, Faria e Sousa confessa, 
"Sospiros inflamados, que cantais

a tristeza com que vivi tão ledo!

Eu mo[u]ro e não vos levo, porque hei medo

que, ao passar $\mathrm{d}[\mathrm{o}]$ Lete, vos percais.

Escritos $\mathrm{p}[\mathrm{e}] \mathrm{ra}$ sempre já ficais,

onde vos mostrarão todos com o

dedo,

como exemplo de males; que eu concedo

que, pera aviso(s) de outros, estejais.

E em quem virdes falsas [e] speranças

do Amor e da Fortuna, cujos danos

alguns terão por bem-aventuranças,

deze[i]-lhe que os servistes muitos

anos,

e que em Fortuna tudo são mudanças,

e que em Amor não há senão

enganos." 104

A primeira quadra abre-se já com uma apóstrofe enfática referida aos próprios versos, «Sospiros inflamados, que cantais / a tristeza com que vivi tão ledo!», em que através de uma expressão paradoxal de natureza conceituosa é revelado o tempo pretérito, quando o emissor lírico vivia feliz no meio das mágoas. A ponto de morrer, indica-lhes que não o irão acompanhar na viagem que está prestes a fazer, porque tem medo de que desapareçam no transe de passarem o rio Lete ${ }^{105}$. A oportuna alusão mitológica lembra, efectivamente, o perigo ameaçador das águas de tal rio para a memória, capaz de fazer perder todas as lembranças. Porém a intenção do emissor lírico é precisamente que náo se esqueça o passado, de tal jeito que o seu testemunho poetizado possa ficar para sempre como mostra desesperada diante dos leitores ${ }^{106}$. É na segunda quadra que se exprime essa vontade de dar às criaçóes próprias a oportunidade de náo partir

a propósito de "Sospiros inflamados, que cantais", que se trata de um texto que o obriga a aceitar as suas próprias carências artísticas como criador literário: "Yo siempre estoy confessando que si a caso sè alguna cosa, lo devo a este Monstro de ingenio, de estudio, y de juizio; pero a toda verdad èl me lo descuenta bien, porque por otra parte me està siempre martirizando; porque si él no ubiera nacido, ó, ya que naciesse, no obrára tanto, yo no estubiera siempre rabiando de embidia; y este Soneto me la haze de modo que me como las manos. Pero si el divino Apolo assi lo quiso, no ay sino tener paciencia: mas no se yo que la pudiesse tener sino con no aspirar a ser Poeta» (Faria e Sousa, em Camóes, Rimas..., pp. 147-148).

104 Azevedo Filho, Lírica de Camóes. 2.Sonetos, t. II, p. 913.

105 «Tal coza como esta nadie pensó dezirla jamâs. Yo, suspiros mios (dize) me estoy muriendo; y no quiero llevaros conmigo al otro mundo, porque tengo miedo de que os perdays al passar el rio del Olvido, en cuyo passaje perecen todas las memorias; y quiero que las aya siempre de vosotros; por tanto quedaos acá, para que siempre, como immortales seays oidos. Quiere dezir que si bien él ha de morirse, no se moriran jamás sus Poemas, y singularmente estos de sus amorosas tristezas» (Faria e Sousa, em Camóes, Rimas..., p. 148).

$106 \mathrm{O}$ desejo de alcançar fama póstuma através da poesia, um motivo temático que, embora esteja também sugerido na imagem mitológica do esquecimento que provoca o rio Lete, aparece presente nesta composição principalmente nos vv. 5-6, constitui um tópico de proveniência horaciana com ampla influência na literatura dos séculos XVI e XVII. O modelo primigénio bem pode ser a Ode IV-3 do autor latino, em 
deste mundo, pois assim terão fama servindo de magnífica lição da desilusão e da dor amorosa.

Nos dois tercetos, interligados sem nenhuma pausa, surge o convite do amante aos suspiros acesos que nascem dos seus males, isto é, aos versos que brotam da sua pena, a fim de ensinarem aos que moram ainda no engano, cuidando ingenuamente que as desgraças são boas venturas, que o Amor e a Fortuna só consentem esperanças incertas. Em suma, cumpre que declarem com firmeza, a partir do exemplo que procede do submisso trato individual do emissor lírico com o Amor e a Fortuna durante muito tempo, as falsidades e as mudanças que estes fornecem ${ }^{107}$.

Como se pôde perceber através da análise levada a efeito destes três sonetos-prólogo, não raro existiu a tendência a interpretar com perspectiva impressionista alguns dos seus versos, decerto os de aparência mais humana, sobretudo pelo concentrado

que agradece muito satisfeito à Musa o favor de lhe ter outorgado a fama como poeta (Manuel FernándezGaliano; Vicente Cristóbal, eds., Horacio, Odas y Epodos, Madrid, Cátedra, 1990, p. 328):

"Quem tu, Melpomene, semel

nascentem placido lumine videris,

illum non labor Isthmius

clarabit pugilem, non equus impiger

curru ducet Achaico

victorem, neque res bellica Deliis

ornatum foliis ducem,

quod regum tumidas contuderit minas,

ostendet Capitolio:

sed quae Tibur aquae fertile praefluunt

et spissae nemorum comae

fingent Aeolio carmine nobilem.

Romae principis urbium

dignatur suboles inter amabilis

vatum ponere me choros,

et iam dente minus mordeor invido.

$\mathrm{O}$, testudinis aureae

dulcem quae strepitum, Pieri, temperas,

o mutis quoque piscibus

donatura cycni, si libeat, sonum,

totum muneris hoc tui est,

quod monstror digito praetereuntium

Romanae fidicem lyrae;

quod spiro et placeo, si placeo, tuum est."

107 Como um exemplo apropriado das tentativas que com diversos critérios pretenderam fixar a cronologia dos poemas camonianos, é conveniente registar que "Sospiros inflamados, que cantais" foi considerado por Maria de Lurdes Saraiva, do ponto de vista temático, um soneto de composição tardia em função do tom pessimista e dramático que revela. Vid. Saraiva, ed., Camóes, Lírica..., vol. II, pp. 87-88. Contrariamente, Azevedo Filho julga que a data do texto, de acordo com fundamentos métricos, teria de ser em princípio menos tardia, porquanto nele são ainda perceptíveis encontros vocálicos da natureza arcaizante: «Tal hipótese [Maria de Lurdes Saraiva] é provável, mas encontra uma dificuldade métrica na ocorrência de encontros vocálicos arcaizantes, ao contrário do que se vê nos sonetos do ciclo de Dinamene, sonetos de plena maturidade poética, onde o regime dos encontros vocálicos, normalmente, obedece ao uso moderno. Por isso, se o soneto pode ser um dos últimos, também pode ser um dos primeiros, pois é sabido que os poetas jovens também cantam desenganos amorosos e pensam na morte, prematuramente, deixando a sua obra e a sua experiência para meditação póstuma» (Azevedo Filho, Lírica de Camóes. 2.Sonetos, t. II, p. 930). 
tom de confidencialidade que destilam, inerente como uma característica destacada a este subgénero da poesia petrarquista. Em tal sentido, torna-se interessante lembrar a existência de uma via de investigação muito perigosa que foi utilizada insistentemente pela maior parte dos biógrafos que se consagraram ao trabalho de apresentar de modo minucioso a vida do escritor. Com efeito, a penosa carência de documentos relativos a Camóes levou muitos camonistas, já desde o século XVII, a formularem conjecturas baseadas apenas nos seus próprios versos, uma estratégia que não seria tão prejudicial se tivesse ficado no âmbito restrito do que é o desígnio de reconstruir o percurso existencial do escritor. Todavia, deve-se consignar que esse hábito infundadamente crítico se converteu sem dúvida numa actividade nociva, porquanto logo determinou que a interpretação de muitos textos e ainda, diga-se também, a atribuição do selo de autenticidade no caso de eles serem problemáticos se vissem danadas gravemente. De tal maneira se consolidaram dois arriscados círculos viciosos que em pouca medida contribuíram para a correcta análise de poesia camoniana: por um lado, cuida-se que os textos oferecem dados biográficos mais tarde considerados fulcrais para a leitura desses mesmos textos; e, por outro lado, julga-se também que as hipóteses biografistas estabelecem a autoria segura de textos discutíveis, os quais mais tarde, uma vez considerados irrefragavelmente camonianos, podem servir de apoio para estender o certificado de autenticidade a outros textos ainda mais duvidosos.

Não parece difícil acreditar que essas duas operaçóes têm uma origem certamente romântica, a confundir-se nelas com clareza a personalidade real do criador literário e a sua actividade especificamente criadora. Tal identificação, obviamente errónea com respeito aos seus princípios essenciais, deve ser posta em causa com mais decisão quando se analisam em concreto os sonetos camonianos, porque é o conteúdo deste género lírico que nomeadamente foi considerado um registo fiel e indiscutível da experiência vital do escritor ${ }^{108}$, esquecendo com simplicidade que as relaçóes entre o mundo do texto literário e o mundo empírico são altamente complexas e de aventurada equiparação, sem se poder dar sempre como certo na vida real o que se afirma na literatura ${ }^{109}$. De acordo com esta concepção romântica do exercício crítico, o labor interpretativo dos textos amiúde se reduz, num processo de intensa subjectivação dos factos poetizados, à análise conforme a letra do que há nos poemas como provável fonte de informação da própria experiência do escritor, de tal forma que se lhes confere um valor documental que não leva em conta a evidente operação transformadora que conduz da realidade à ficção. E se isto acontece de uma perspectiva geral com relação a qualquer criador, cumpre advertir que no caso de Camóes a tentação de encontrar nos versos o que os documentos náo podem demonstrar foi ao longo do tempo uma prática nefastamente habitual que, aliás, deu como resultado nele, como Jacinto do Prado Coelho tem indicado, a circunstância de ser quase relegado o escritor em prol do homem físico:

108 «La produzione lirica e in particolare i sonetti costituiscono uno specchio della sua tormentata e avventurosa esistenza» (Leo Negrelli, Il sonetto portoghese, Firenze, Il Fauno Editore, 1964, p. 274).

109 Vid. Vítor Manuel de Aguiar e Silva, «... um Camóes bem diferente...», Colóquio-Letras, 47 (Agosto 1979), p. 6. 
"Quanto a Luís de Camóes, o facto de sabermos tão pouco (e com uma ignorância aparentemente definitiva) sobre a sua vida exterior podia, e deveria, concentrar-nos no estudo da sua obra, por ela mesma, e náo pela biografia que falta. Entretanto, o preconceito da literatura como documento, a subestimaçáo do artista em relaçáo ao homem (...), por outro lado o vezo de pesquisar anedotas, o gosto de intuir almas à distância, continuam a aguçar o engenho de biógrafos e romancistas do passado. E não é sem um desolado sentimento de inutilidade que lemos páginas e páginas sobre os vazios e as variadíssimas hipóteses da biografia camoniana. $\mathrm{Na}$ verdade, nem o pouco que há nela averiguado nem o muito que falta averiguar permitem avançar um milímetro sequer no conhecimento da Lírica e da Epopeia como obras de arte." 110

Existe um pormenor marcantemente ilustrativo desta espinhosa particularidade que vem caracterizando há muito tempo, com lamentável frequência, o estudo de poesia lírica camoniana. $\mathrm{Na}$ segunda edição das Obras de Camóes arrumadas pelo Padre Tomás José de Aquino, vinda à luz em 1782, figura um retrato do escritor de corpo inteiro que leva ao pé uma inscrição centónica feita com versos seus. Pois bem, isso é perfeitamente um símbolo muito apropriado da maneira semelhante de numerosos camonistas praticarem uma interpretação biografista da obra do poeta, tirando proveito dos seus versos à moda de um centão, sem concerto nem ordenaçáo, para os fazer coincidir caprichosamente com as teses das suas exposiçôes sobre a vida de Camôes. Há que dizer que até certo ponto isso seria desculpável, no entanto, se é que, no que diz respeito a este obstinado e enfadonho costume de extrair dos textos camonianos leituras de índole biografista, estivesse a reflectir-se em último termo a influência do modelo poético-vital de Petrarca.

Como já se disse, o poeta italiano fixa uma nova e revolucionária conexão entre experiência pessoal e prática literária, de grande alcance se é que se tem em vista designadamente a tradiçáo da poesia provençal e do Dolce stil nuovo, que faz que a distância entre o homem e o criador se torne menor por meio da ficção poética ${ }^{111}$. No Canzoniere, Petrarca elabora a "novela íntima de Laura» ${ }^{112}$ libertando a poesia das rígidas convençôes da ideologia cortês, as quais faziam que se considerasse em certa medida incrível qualquer desejo de ver nas realidades fingidas do poeta as verdades reais da pessoa empírica. Instaura-se assim na obra do escritor aretino um ar de indubitável autenticidade literária, apresentando-se a fábula dos próprios versos como se se tratasse de uma realidade literalmente vivida pelo criador literário que os escreve ${ }^{113}$.

110 Jacinto do Prado Coelho, "Camôes, um lírico do trascendente», em A Letra e o Leitor, 2a ed., Lisboa, Moraes Editores, 1977, p. 16.

111 Cfr. Pina Martins, «Petrarca, esse primeiro...», p. 45.

112 Arturo Farinelli, «Petrarca en Espańa y Portugal», em Poesía y crítica. Temas hispánicos, Madrid, CSIC, 1954, p. 44.

113 «Petrarca (...) fue quien liberó el arte lírico del convencionalismo cortés, máxima distancia entre autor y poeta, y le hizo dar el paso decisivo hacia la subjetividad, es decir, hacia la distancia minima. Con ese paso, Petrarca señaló la norma a la lírica de los siglos venideros" (Fernando Lázaro Carreter, De poética y poéticas, Madrid, Cátedra, 1990, p. 37). 
Com efeito, está a nascer um novo conceito de poesia que se destaca principalmente pela característica, ignorada até essa altura ou não explorada devidamente, de o eu do escritor que se reflecte nos versos revelar sinceramente as suas mais íntimas experiências amorosas particulares:

"De entre o legado do dolce stil nuovo que acolhe e reformula, Petrarca concede particular relevo ao princípio da autenticidade lírica: a poesia é expressão (sincera, isto é, que como tal se impóe ao leitor) de algo que foi vivido (sentido, sofrido) pelo poeta; se não, reduzir-se-ia à exploraçáo (porventura dotada de mestria, mas inane) de convençóes literárias (com matriz provençal). Petrarca integra este princípio na sua poética do desafogo, que por seu turno se tornará um tópico obrigado do petrarquismo mediato."114

Não deve espantar que uma boa parte do petrarquismo europeu, por tal razáo, recolha esse traço fundamental e o cultive com enorme entusiasmo através de inúmeros poetas que se não reduzem nas suas obras à imitação de elementos puramente formais e temáticos, mas também recolhem a imagem do amante sinceramente atormentado que Petrarca transmite no Canzoniere, estreitando as ligaçóes entre obra e vida ${ }^{115}$. Decerto, é evidente que Camóes não deixou de prestar atenção também a essa nota tão inovadora do modelo inaugurado pelo poeta italiano, reduzindo igualmente por seu turno a mesma distância entre obra e vida no campo da ficção, e até com ênfase mais dramática em muitos casos. Por isso seria mesmo aceitável que diversos camonistas se deixassem vencer pela inclinação de crer, de modo muito singelo, que a mensagem dos versos líricos do escritor de Os Lusíadas é na verdade a confissão fidedigna do escritor na qualidade de pessoa de carne e osso.

No entanto, e é aqui que bate decisivamente o ponto fulcral da tendência a ler em chave biográfica os textos de Camóes, convém reparar em que a atitude extremamente confidencial que Petrarca desvenda nos seus poemas é apenas a primeira formulação de um tópico ideológico, a imitatio vitae, que consiste, em sentido preciso, em aparentar que as próprias criaçóes literárias são o produto de uma experiência verídica vivida pelo mesmo emissor lírico. Como é natural, portanto, não se pode deduzir daí que as supostas confissóes que descortinam os poemas camonianos sejam necessariamente mais do que uma outra perpetuação de um lugar comum de grande êxito, com origem no exemplo petrarquiano, porque está bem de ver que o grau da imitação que Camôes realiza não se detém na apropriação de motivos temáticos e de estilemas, mas também atinge a essa sensação de magoante verdade que o autor do Canzoniere quis comunicar de maneira fingida na sua obra. Um detalhe curioso e muito revelador em tal sentido, digno de ser destacado pela sua significação, é que a maioria dos investigadores biografistas camonianos se tenham dedicado especialmente a realizar leituras existenciais apenas dos textos do escritor correspondentes à medida nova, quer dizer-se, de filiação petrarquista, sem submeter à mesma classe de exegese os textos

114 José Carlos Seabra Pereira, «Para o estudo das Incidências Augustinianas na Lírica de Camôes», em Actas da IV Reunião Internacional de Camonistas, Ponta Delgada, Universidade dos Açores, 1984, p. 439.

115 Vid. Cruz., Imitación y transformación:..., p. 26. 
da medida velha, porventura com o pensamento, originado por imperfeitas focagens críticas, de serem os poemas escritos de acordo com esse código estilístico muito aptos para se descobrir a interioridade vital do escritor.

Certamente um comportamento habitual quando se realiza a leitura de textos literários petrarquistas, talvez provocado pelo especial carácter da linguagem de escola que é utilizada, consiste em imaginar que as aventuras amorosas que se poetizam foram inspiradas por sucessos idênticos pertencentes ao âmbito da realidade, ignorando-se assim que tais textos estáo concebidos consoante um conjunto de normas que fazem parte de uma cultura literária determinada que possui as suas próprias chaves tópicas. Entre essas normas deve-se considerar que o amante que se retrata fingidamente nos versos não é na verdade uma transposiçãa exacta, isto é, um alter ego, pontual e fiel, do escritor que lhe dá vida literária através da criação poética. A tentativa de identificar ingenuamente os pormenores sentimentais de tal amante e as hipotéticas vivências de tal escritor constituem uma prática ilusória e banal, além de supor um costume crítico perigoso para alcançar a correcta compreensão da essência literária da poesia petrarquista. De modo semelhante supóe ao mesmo tempo uma outra fabulosa inutilidade tentar estabelecer a personalidade real da amada que é cantada poeticamente, pois ela aparece também configurada ficticiamente segundo uma colecçáo de traços físicos e espirituais convencionais que a afastam afinal de qualquer modelo verdadeiro que a pudesse inspirar. A necessidade de não desprezar estes dois pressupostos teóricos no concernente à leitura que se deva fazer da poesia petrarquista, válidos aliás para a abordagem criteriosa de qualquer produto literário, foram bem destacados por Michel Dassonville, como principais conclusóes, num excelente estudo em torno das peculiaridades do especial código psicológico que Petrarca fixa com o Canzoniere:

"La première est que l'amant pétrarquiste est un personnage de papier, qu'il est toujours illusoire d'identifier avec le poète. Il n'a d'autre individualité que celle de l'oeuvre écrite. De l'ordre du vécu, si tant es qu'il y participe un moment (et il y participerait si le poète nous faisait confidence à travers l'Amant d'une expérience qu'il a lui-même vécue), il est vite entraîné dans l'ordre du conçu et comme métamorphosé.

La deuxième conclusion qui s'impose est qu'il n'est pire erreur que celle qui, non contente d'identifier l'Amant au poète, s'acharne à rechercher l'état-civil de la Dame. Etait-ce Laure de Noves ou Laura de Sabran? Et qui étaient Olive, Cassandre, Marie, Délie? Qui ne se souvient de ce peintre de l'antiquité qui avait peint des cerises si merveilleusement que les oiseaux du ciel essayèrent de les picorer? Par dieu, comment s'appelaient les demoiselles d'Avignon?"116

Apesar destas prevenções mesmo de lógica ilação, se se reflexionar em volta da própria índole imaginária da criação literária, é inegável, todavia, que no caso da poesia lírica de Camóes se observa como um sem-fim de estudiosos, precisamente por causa da penúria documental que envolve a vida do escritor, têm sucumbido diante

116 Michel Dassonville, "Réflexions sur le Pétrarquisme», em Missions et démarches de la critique (Mélanges offerts au Professeur J. A. Vier), Paris, Librairie C. Klincksieck, 1973, p. 593. 
do desejo de tomar por verdadeiro o que muito provavelmente apenas seja ficção, não excluindo com esse comportamento crítico o homem biografiável do circuito restrito da comunicação poética. As tendências analíticas mais modernas promovem convictamente a necessidade de submeter a mensagem lírica, para assim elucidar melhor os seus aspectos puramente estéticos, a um implacável e rigoroso processo de despersonalizaçáo que é mais patente ainda em face de textos pertencentes a autores petrarquistas ${ }^{117}$. No entanto, a repercussão de tal pensamento teórico no estudo da obra camoniana não tem deixado sentir o seu efeito com grande intensidade mesmo na altura presente, embora haja que fazer sobressair diferentes ressalvas, devido de maneira fundamental ao peso da herança legada através de várias centúrias em que foi preponderante em sumo grau a preocupação de esquadrinhar nos versos de Camóes referências verdadeiras quanto à sua vida.

Em face de aproximaçóes deste carácter, devedoras em excesso de costumes metodológicos que hodiernamente teriam de estar já ultrapassados, porventura um dos trabalhos de interesse mais sobressaliente no que atinge às relaçóes entre verdade $\mathrm{e}$ poesia na obra camoniana seja o artigo intitulado ilustrativamente "Camóes: biografia e lirismo", de David Mourão-Ferreira, uma abordagem crítica certamente fundamental além de muito valente e perspicaz ${ }^{118}$. É um trabalho valioso em que se parte da lamentável comprovação de mesmo na actualidade se empregarem prolixamente focagens biografistas que visam mais à individualidade de Camóes do que propriamente à essência da sua poesia, tratando de fantasiar o seu percorrido vital em lugar de concentrar-se no estudo dos elementos singulares que determinam o seu estro literário. Com uma atitude que em certos casos reflecte uma dura ironia, Mourão-Ferreira dá a alarme sobre o que é o espectáculo crítico de diversos camonistas chegar a ignorar propositadamente o sentido estético dos versos camonianos, a preferirem em espantosa decisão "o autor à obra, o criador à criação, o pré-texto ao texto» ${ }^{119}$. Em seu entender, parece absolutamente incrível que se possa acreditar com toda a singeleza que em Camóes há um imediato elo de causa e efeito entre a sua vida e a sua poesia. Como ele próprio afirma com evidente sarcasmo, o terrível desta prática teórica não é apenas o simples pensamento de crer que o conhecimento biográfico seja crucial para ler em condiçôes óptimas os textos, mas até a convicção de isso ser também de extraordinário relevo para determinar do ponto de vista estético o seu valor:

117 Por exemplo, são sintomáticas as novas perspectivas que revelam as últimas investigaçôes consagradas ao estudo da poesia do autor espanhol Garcilaso de la Vega, tradicionalmente examinada de acordo com pressupostos biografistas que prestaram especial atençáo ao conteúdo vital que aquela transmitiria quanto à relação sentimental que ligou este poeta com a dama Isabel Freire, sua musa amorosa. Vid. Pamela Waley, "Garcilaso's Second Eclogue», Modern Language Review, LXXII (1977), pp. 585-596; Frank Goodwyn, «New Light on the Historical Setting of Garcilaso's Poetry», Hispanic Review, 46 (1978), p. 1-22; Nadine Ly, "Garcilaso: une autre trajectoire poétique», Bulletin Hispanique, LXXXIII (1981), pp. 263-329; David Quinn, «Garcilaso's Égloga Primera: Autobiography or Art», Symposium, XXXVII (1983), pp. 147-164; Luis Iglesias Feijoo, "Lectura de la Egloga I", em Actas de la IV Academia Literaria Renacentista. Garcilaso, Universidad de Salamanca, 2-4 de marzo de 1983, Salamanca, Ediciones Universidad de Salamanca, 1986, pp. 61-82.

118 David Mouráo-Ferreira, "Camóes: biografia e lirismo», em Kurt Levy, Ricardo Sternberg and Laura Bulger, eds., Camóes and His Times, Toronto, St. Michael's College - University of Toronto, 1987, pp. 157-168.

119 Mourão-Ferreira, «Camóes: biografia...», em Levy, Sternberg and Bulger, eds., Camóes and..., p. 159. 
"É evidente que tudo isto deriva de um arraigado preconceito romântico segundo o qual será indispensável o conhecimento da biografia de um autor, não só para interpretar a sua obra, mas ainda para devidamente a valorizar. E ninguém melhor -isto é, pior- que o crítico francês Sainte-Beuve assumiu e formulou semelhante preconceito ao considerar que, em relação a qualquer autor, se torna imprescindível tentar previamente devassar-lhe o rol de roupa suja, inventariarlhe o bragal, registar os depoimentos de quantos o viram em perigos ou ouviram ressonar, coligir as anedotas que corram a seu respeito (...)."120

Segundo se pode deduzir facilmente, as lúcidas reflexôes de Mourão-Ferreira marcam um ataque exasperado mas legítimo dirigido àquelas concepçóes que baseiam o seu desígnio na mera leitura realista e humana das peças camonianas, sem repararem na complexa operação de mudança que faz converter os materiais vitais em materiais literários. No seu dizer, fora do próprio âmbito da biografia como género independente, é uma tarefa desnecessária e perturbadora tentar decifrar conteúdos existenciais, com uma referencialidade nítida, no património artístico do escritor, e ainda mais procurar desesperadamente a identidade das supostas damas, se é que elas existiram na verdade, a que os seus poemas estariam dirigidos ${ }^{121}$. Realmente o importante para Mourão-Ferreira funda-se no facto obrigatório de concentrar o exame literário nos aspectos estéticos dos textos considerados de jeito isolado, sem cair na tentaçáo de ver significados profundos que aludiriam fabulosamente a episódios mágicos da vida do autor.

Em definitivo, conforme é factível constatar através da breve panorâmica que se delineou ao longo destas páginas, um aspecto de imensa gravidade na análise mais habitual da poesia camoniana, com especial repercussão nas três peças apresentadas como sonetos-prólogo, é a quase constante mistura de elementos existenciais e de elementos estéticos na sua focagem crítica. Tal como se disse, trata-se de um defeito metodológico que possui uma marcada origem romântica concretizada, de modo especial, em duas dimensóes. Em primeiro lugar, tende-se a acreditar que o valor de uma obra literária é dependente estreitamente do grau de sinceridade que patenteia, de tal forma que se póe em prática com perniciosas consequências o axioma teórico de se considerar boa uma obra se é que nela se destaca um tom confidencial elevado, enquanto o juízo que essa mesma obra merece resulta inferior se é que aí está sugerida uma impressão de falsidade ${ }^{122}$. Por outro lado, convém acrescentar que a influência

${ }^{120}$ Mourẫo-Ferreira, "Camóes: biografia...», em Levy, Sternberg and Bulger, eds., Camóes and..., p. 160.

121 "Quem "era" a dama? Questão ociosa. Se fosse imprescindivel sabê-lo, não haveria, tão-pouco, nos dias de hoje, poema de amor que dispensasse, em apêndice ou a abrir o próprio texto, o retrato e a fotocópia do cartão de identidade da respectiva musa, o que, como é óbvio, não deixaria de trazer, em muitos casos, as mais sérias complicaçóes» (Mourão-Ferreira, "Camôes: biografia...», em Levy, Sternberg and Bulger, eds., Camóes and..., p. 165).

122 "Ora isto póe, antes de mais nada, o problema do romantismo. Porque o romantismo - e melhor será talvez dizer, para reduzir as possibilidades de confusão: o romantismo do eu-ignora efectivamente a distinção entre autor e obra; não é por acaso que tão frequentemente se esquecem os críticos de nos dizer se é desta ou daquele que estão falando; é isso um remanescente do romantismo, que ainda fará muitas vítimas, e cuja eliminação nos livraria do falso problema da intenção do autor, e nos deixaria perante o verdadeiro problema de se inquirir o que seja uma obra sincera. Numa obra expressamente confessional a intenção será a própria sinceridade - mas o confessional 
da ideologia romântica na avaliação estética dos produtos literários também se torna manifesta quando se insiste em oferecer uma imagem do criador inteiramente intangível, genial e mítica, mesmo que intensamente humana, um retrato sempre extraordinário e dominado pela originalidade, o qual constitui uma noção que, pelo visto nas páginas antecedentes com relação a "Em quanto quis Fortuna que tivesse", "Eu cantarei do Amor tấo docemente" e "Sospiros inflamados, que cantais", se aplicou em larga medida e com regularidade pasmosa ao caso específico de Camóes.

No entanto, como é natural, as criações literárias precisam pelas suas condiçôes inerentes um sistema analítico próprio que fixe restritamente o objecto de estudo no sentido mais literal possível do texto artístico concreto ${ }^{123}$. As leituras da lírica camoniana autobiographico modo ${ }^{124}$, com a sua insistência em focar os poemas consoante imaginárias chaves externas, não fazem mais do que revelar, no fim de contas, a imensa quantidade de invençóes que suscita a pobreza documental que encerra a verdadeira existência de Camôes. Além disso, mostram com pouco rigor uma espécie de anacronismo metodológico que, a interpretar sem custo o tempo passado sob uma perspectiva hodierna, buscando deitar luz em volta daqueles assuntos da vida camoniana que ficam mais sombrios, se fundamenta na projecção de concepçóes que são específicas do tempo presente sobre os factos estudados do pretérito.

Difícil parece saber com segurança, se é que os versos líricos camonianos são fidedignas confissóes disfarçadas de passos autênticos da vida do escritor, mas, em todo o caso, cumpre não esquecer a diferença básica que se tem de estabelecer no campo da criação poética entre o $e u$, que funciona no texto como emissor lírico, e o autor real e empírico, de existência verdadeira como pessoa corpórea, uma discriminação muito habitual no âmbito dos estudos narratológicos, embora quase ausente nos estudos de poesia, e especialmente rara, ainda, no exame literário da obra lírica camoniana. Talvez um dos maiores erros que se tenha cometido na contemplaçáo dos versos de Camóes, em suma, seja acreditar, cedendo sob a força de muitas tentaçôes, que se está perante mentiras verdadeiras e não verdades mentirosas. E as composiçóes camonianas que se inserem especialmente na tradição petrarquista do soneto-prólogo, onde prevalece a mentira tópica sobre a verdade existencial, a confidência fingida mais do que a confissáo sincera, até patenteiam com força irreprimível a insuportável leveza desse paradoxo.

\footnotetext{
não é "obra" senão do ponto de vista dos românticos, que trocaram as duas noçôes, e fizeram de "estético", ou "construído", sinónimo de "falso", e de "sincero" fizeram sinónimo de "belo", numa significativa equivalência com a assimilaçâo dos neoclássicos entre "beleza" e "razâo" (Adolfo Casais Monteiro, Estrutura e Autenticidade na Teoria e na Crítica Literárias, Lisboa, Imprensa Nacional - Casa da Moeda, 1984, p. 44).

123 «De facto, como sabemos, a literatura ainda não obteve um geral reconhecimento de algo que se diria óbvio, e que se pode formular desta forma elementar: visto que há literatura, deve haver também uma teoria e uma prática que lhe sejam específicas. Ora, pelo contrário, o que se verifica é a persistência com que estudos que prometem ser sobre ela, se ocupam afinal daquilo que "está antes dela", e daquilo que "vem depois dela" " (Casais Monteiro, Estrutura e Autenticidade..., p. 99).

124 Vid. Iglesias Feijoo, «Lectura...», pp. 61-82.
} 